Historic, Archive Document

Do not assume content reflects current scientific knowledge, policies, or practices. 



\section{HALLAWELL'S FALL CATALOG : OF BULBS}

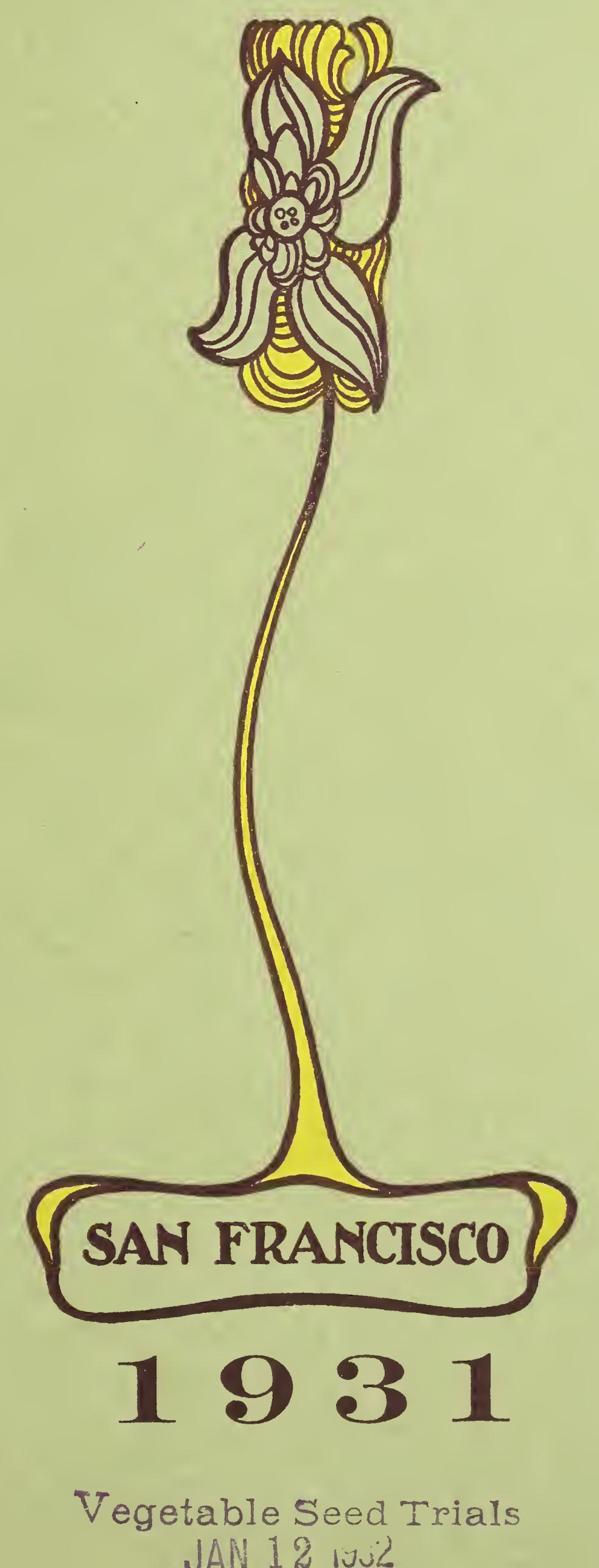




\section{Hallawell Seed Company, Inc.}

SAN FRANCISCO, CALIFORNIA

\section{Store-256-258 Market Street \\ Telephone SUtter 8981 Nursery-Quintara St. and 23rd Ave. Telephone MOntrose 7043}

Visitors are always welcome at our Nursery. located in the Sunset District, and which is open from 7:30 A. M. to 5 P. M., daily excepting Sundays. To reach our Nursery, take the No. 17 car to Quintara Street and 20th Avenue, and walk three blocks west.

We carry a full assortment of Ornamental Shrubs, Perennials, Roses, Fruit Trees and Berries in season.

\section{PLEASE ADDRESS ALL CORRESPONDENCE TO 256 MARKET STREET}

\section{WHEN AND HOW TO ORDER BULBS}

The best time to order your Bulbs is just as soon as this catalog reaches you. The Bulbs may not have arrived by then, but your order will be given immediate attention, and be filled just as soon as the stock arrives. At the first of the season there are no sorts sold out, and besides the Bulbs flower better when planted early.

We prepay charges within the 4th zone on all bulbs listed in this catalog. Herbaceous and Perennial Plants are not prepaid, so if desired by Parcel Post add postage as stated on page 18.

\section{HOW TO HANDLE BULBS WHEN THROUGH BLOOMING}

Spring flowering bulbs can be left in the ground after blooming provided they are in an isolated place where they can remain dry throughout the summer, but in most gardens the space is too limited to warrant this as continuation of bloom is desired. If this is the case, it is advisable to lift up the bulbs carefully after they are through bloom, preferably a few weeks later, and transplant them close together in any convenient corner of the garden; give them one good watering and let them remain until the foliage has died down completely, at which time the bulbs will be fully ripened and can be dug up and stored away in shallow trays in a cool, airy place until the proper time to set them out again. Never cut off the foliage when green as this will weaken the bulbs and often prevent them from blooming. If bulbs are left in the ground after the blooming season, where other plants are growing, they may rot or fail to bloom the following season as they will not have the proper rest.

\section{HYACINTH GLASSES}

Hyacinth Glasses: Tall type and Bell type; green, 50c each; 60c postpaid within 4th zone.

Culture in Glasses: To grow Hyacinths in water, they should be placed so that the base of the bulb does not quite touch the water. The glasses should then be set in a cool, dark closet, or in the cellar, until filled with roots, when they may be brought in to the light. Give as much fresh air as possible, and a temperature of not over sixty degrees, until the spikes are developed. To put them at once into a room with a temperature of say, seventy degrees, would cause them to flower prematurely.

\section{PREPARED BULB FIBRE}

This material is very popular for growing bulbs in, and is especially adapted for use in the home, being clean and odorless.

It contains all the necessary plant food for almost all kinds of plants.

Before using it should be thoroughly moistened, and the bulbs planted in the same way as if soil were used. A special feature of this material is that Bulbs can be grown in it in jardinieres, fern dishes and other receptacles without drainage. After watering, the jardinieres or dishes should be turned on side to allow any surplus water to drain off.

The treatment after planting in this material is the same as when planted in soil.

Fibre comes moist (postage additional): 1 lb., 15c; 5 lbs., 60c; 25 lbs., $\$ 2.50 ; 100$ lbs., $\$ 8.00$.

\section{NON-WARRANTY}

Most of the failures with seeds and bulbs are due to causes entirely beyond our control, such as unfavorable weather, too deep or too shallow planting, slugs, etc.; therefore, Hallawell Seed Co. gives no warranty, express or implied, as to description, purity, productiveness, or any other matter of any seeds, plants, bulbs, etc., they send out, and will be in no way responsible for the crop. If the purchaser does not accept the goods on these terms they are to be returned at once. 


\section{Hallawell's Darwin and Breeder Tulips}

The most satisfactory of all Tulips. They are stately in appearance, attaining a height of 24 to 30 inches, and producing beautiful globular flowers of heavy texture in a large range of colors. They bloom in April and May and are unsurpassed for bedding and cutting.

Tulips can be planted from October till late in December. They require a moderately rich soil, which should be well drained. If the soil is in poor condition, use a little bone meal or well-rotted manure. Plant the bulbs 6 or more inches apart and set the tops 3 inches below the surface. If the soil is heavy, place a small quantity of sand at the base of each bulb. They will remain in bloom for a longer period if planted in a light shaded location.

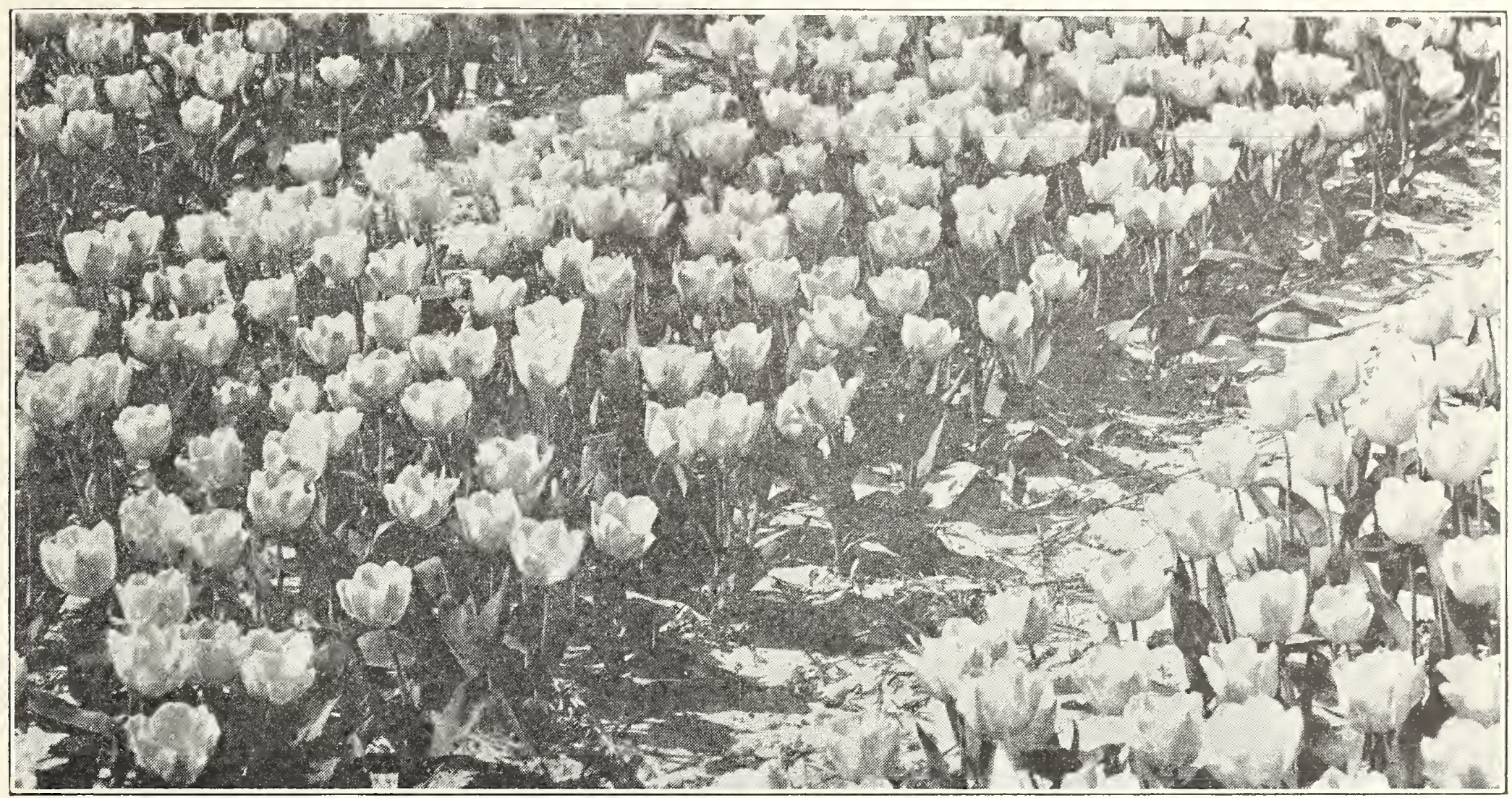

\section{DARWIN TULIPS}

All bulbs listed in this catalog are postpaid within the Fourth Zone.

The figure following the name indicates the relative time of flowering

Per doz. Per 100

Afterglow: 4. A beautiful blending of deep rosy orange with amber shadings at edge of

petals; height, 26 in.....................................................

Anton Roozen: 2. Large vivid rose-pink,

edged pale rose; height, 28 in...............................

Baronne de la Tonnaye: 4. Bright rose

margined blush rose; height, 26 in...................

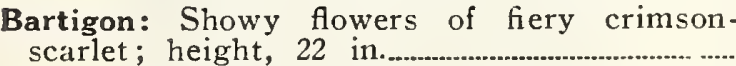

Bleu Aimable: 4. Pale lavender; a beauti. ful flower of a very distinct shape; height, 25 in.

Centenaire: 1. Beautiful deep rose flushed
claret; enormous flowers of perfect shape;

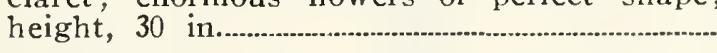

Clara Butt: 4. Clear pink flushed salmon-

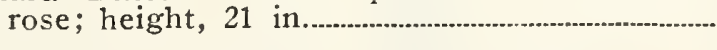

Dream: 2. Pale heliotrope, changing to lavender; height, 27 in............-...-............................

Edmee: 4. Vivid shade of cherry-rose, edged

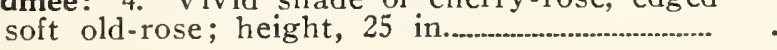

$\$ .75 \$ 5.00$

$.75 \quad 5.50$

$.60 \quad 4.25$

.65

.75

.60

.60

.70

.75
Farncombe Sanders: 2. Scarlet with rosy

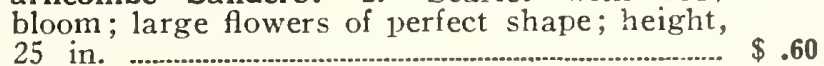

Per doz. Per 100 25 in

Feu Brilliant: 2. Bright scarlet; very large; height, 25 in..............................................................

Flamingo: 4. Shell-pink; pointed flowers;

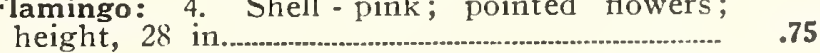

Inglescombe Yellow: 4. Glossy canary yellow; large globular flower; height, 20 in............. .60

King Harold: 3. Rich deep mahogany-red;

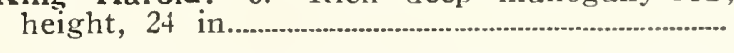

La Fiancee: Rich-rose, shading to old-rose and delicate pink at edges. A splendid variety of large size; height, 30 in................... .85

La Tulipe Noire: 3. Very dark maroon-black; height, 25 in.

Madame Krelage: 2. Bright rosy pink, margined pale silvery rose; height, 28 in................

Marconi: 3. Blue-purple, with violet base; 5.00 $\begin{array}{ll}.60 & 4.25\end{array}$

$\begin{array}{ll}.75 & 5.50\end{array}$ 


\section{DARWIN TULIPS (Continued)}

Per doz. Per 100

Massachusetts: 5. Vivid pink, edged rosy white, very late bloomer; height, 26 in.

Melicette: 3. Soft lavender; inside dark lavender-violet; height, 25 in...........................................

Petrus Hondius: 2. Bright carmire-rose, an unusually brilliant variety in this color; height, 28 in

Philippe de Commines: 1. Velvety purple-maroon; height, 24 in.........................

Pride of Harlem: 1. Deep rose suffused and brightened with scarlet; very large; height, 25 in.

$.70 \$ 4.75$

1.00

7.50

.70

4.75

.75

5.00

Prince of the Netherlands: 3 . Glowing cerisescarlet, edged rose; extra large flower height, 31 in

Princess Elizabeth: 2. Clear deep pink, changing with age to rose-pink; height, 26 in.

Professor Rauwenhof: 3. Bright cherry-red with scarlet glow inside; enormous; height, 28 in.

Reverend Ewbank: 2. Soft heliotrope shading to lavender; the best of this color; height,

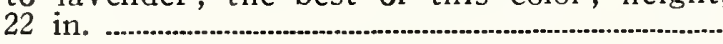

White Queen: 2. Almost pure white when mature, at first tinged pale rose; height, 24 in.

Whistler: 3. Brilliant crimson, with beautiful purplish bloom over outer petals; lieight, 24 in.

Special Collection: Two of each of the above sorts (58 bulbs), named separately.....................

Field Grown Mixture of Darwin Tulips.

(n) $1000, \$ 33.50$

Hallawell's Special Mixture of named Darwin T'ulips...................... 1000, \$42.50

\section{BREEDER TULIPS}

This fine type is very similar to the Darwin in their tall, strong crowth and with even larger flowers and bloom about strong growth and with even larger flowers and bloom about
the same time, but have an entirely different range of colors, comprising bronze, terra-cotta, orange-brown and other artistic tones that are altogether wanting in the Darwins.

Per doz. Per 100

Apricot: 3. Ruddy apricot, edged bronzy buff, with yellow base and olive halo; height

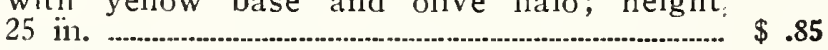

Bronze Queen: 4. Soft buff, shaded bronze; inside tinged golden bronze; height, 28 in......

Cardinal Manning: 4. Dull wine-red flushed rosy bronze, changing to rosy violet; height, 30 in.

Dom Pedro: 3. Rich coffee-brown, shaded matoon; inside mahogany-red; height, 24 in.

Feu Ardent: Very brilliant red, large cupshaped bloom; height, 24 in.................................

Louis XIV: 3. Immense globular flower, rich purple with golden bronze margin; inside bronzy purple; height, 28 in.................................

Madras: 3. Dark bronze, yellow and gold;

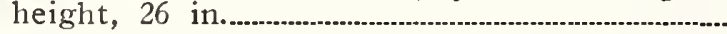

Panorama: 2. Deep orange shaded mahog.

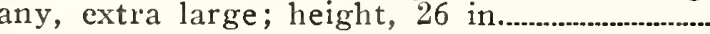

Prince of Orange: 3 . Rich terra-cotta red, margined orange-red; height, 27 in.................

St. James: 2. A large, beautiful Tulip. Color chestnut-brown flushed bronze gradually passing to gold at the margin; height, 28 in.

Breeder Mixture: Made up from named sorts only

\section{.85}

.65

.75

.85

.85

.75

.75

.65

.85

.75

.75
4.75

4.75

3.50

4.50

5.00

5.00

\section{TULIP SPECIALTIES}

Each Per doz. Per 100

Ambrosia (Cottage): Very large, sal.

mon-orange, outside flushed lilac-rose;

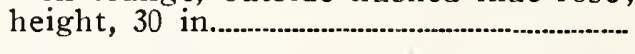

$\$ \quad 15 \quad \$ 1.50 \quad 11.00$

Bacchus (Breeder): Dark violet - blue with darker bloom on outside of petals: large, long flower, 28 in...........

City of Harlem (Darwin): Immense verinilion-scarlet, blue-black base, 27 in.

Dido (Cottage): Large, rich orangerose tone with margin of bright orange-yellow; height, 24 in..................

King George V (Darwin): Brilliant cherry-rose; immense flower of unusual substance; height, 25 in

Lucifer (Breeder): Dark orange with rosy bloom; inside scarlet - orange; enormous flower on tall stem; 28 in....

Orient (Cottage): Large bold flower of a remarkable color; rich rosy mauve slightly touched with amber at the edges of the petals; height, 30 in...........

Prince of Wales (Darwin): Very bright cherry-red; a large flower of remarkably brilliant tone; height, $28 \mathrm{in........}$

Collection of two each of the above eight sorts

$\begin{array}{lll}.10 & 1.00 & 6.75\end{array}$

$\begin{array}{lll}.09 & .90 & 6.25\end{array}$

$\begin{array}{lll}.17 & 1.75 & 12.00\end{array}$

$\begin{array}{lll}.11 & 1.15 & 8.00\end{array}$

$\begin{array}{lll}.12 & 1.25 \quad 8.75\end{array}$

$\begin{array}{lll}.15 & 1.50 \quad 11.00\end{array}$
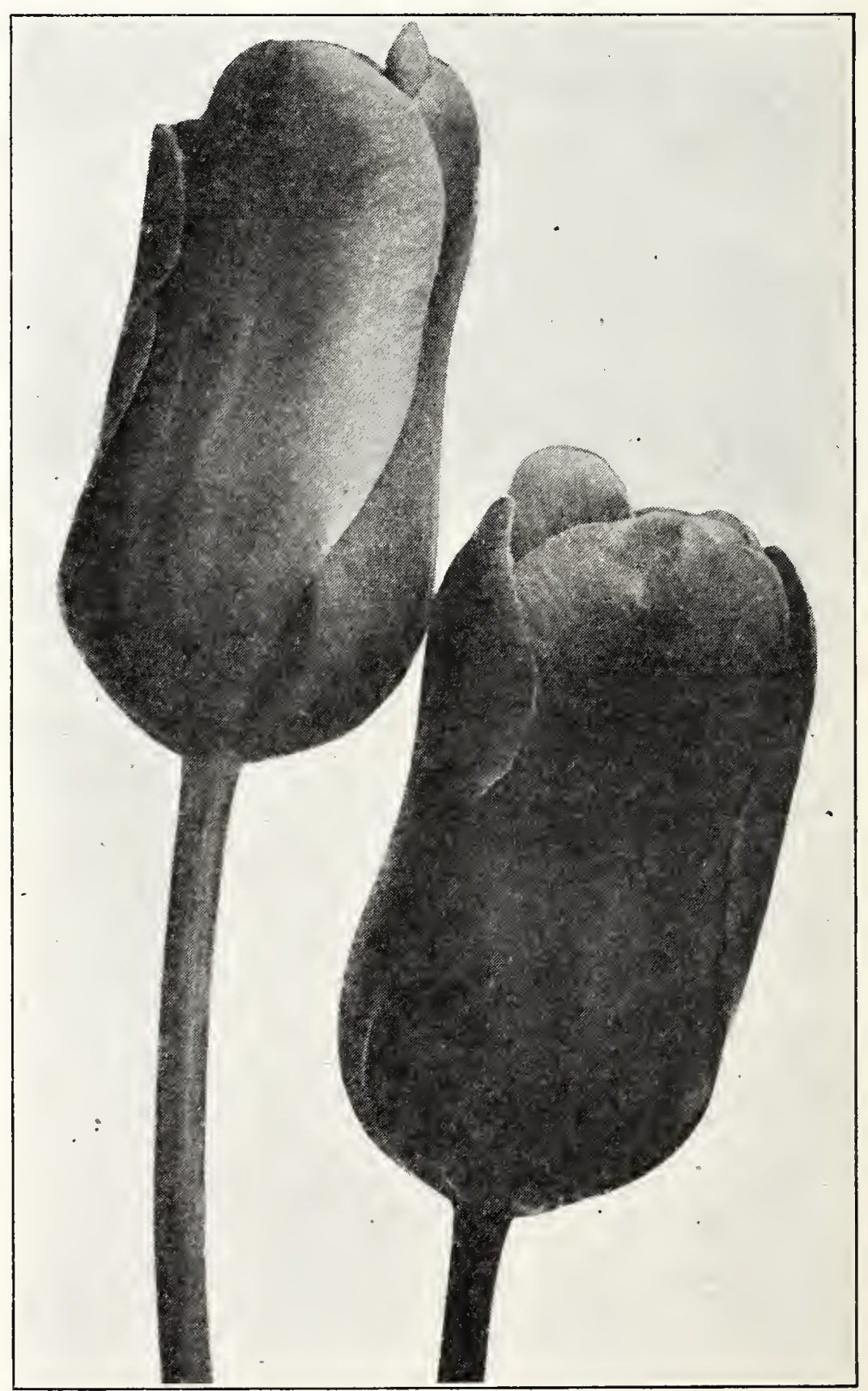

Orient Tulip 


\section{COTTAGE or MAY TULIPS}

This beautiful class is also very popular, although the stems are not quite so long as in some of the Darwin varieties. They, however, come in certain forms and colors not to be found in the other groups.

\section{(Postpaid within Fourth Zone)}

The figure following the name indicates the relative time of Aowering.

Per doz. Per 100

Gesneriana Major: 3. Brilliant crimson-scarlet with blue-black base; a superb variety with pointed petals; height, 28 in...-..--.----.--..

Inglescombe Yellow: See under Darwin Tulips. .75

John Ruskin: 3. Salmon-rose, edged soft lemon-yellow; inside heliotrope with golden border and base. Large egg shaped flower of graceful form; height, 16 in

Maiden's Blush: (Picotee) 3. Pure white margined carmine-rose, pointed petals; height, 20 inches

Moonlight: 1. Very long oval-shaped flowers

Mrs. Moon: Golden yellow with reflexed pointed petals; height, 24 in...............................

Orange King: 4. Glistening deep orange; inside deep orange-scarlet with yellow base; sweet scented; large globular flowers; height, 24 in.

Rembrandt Tulips Mixed: The large flowers are striped and feathered and come in a variety of pleasing colors. The stems aver-

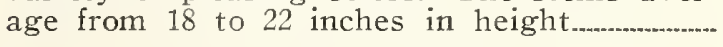

Parrot or Dragon Tulips Mixed: These come in very bright colors, each flower having a combination of red, green, black and yellow. The petals are large and deeply fringed. The stems are rather weak

\section{WILD TULIP SPECIES}

Clusiana (Little Lady or Candystick Tulip): The dainty flowers are small but quite distinct. Outer petals, white with cherry stripes. Excellent for the rock garden, height about 9 inches. It should be planted in light soil 6 or 9 inches deep. Per doz., $90 \mathrm{c}$; per 100, $\$ 6.50$.

Kaufmanniana (The Water Lily Tulip): Large creamy flower, brilliantly marked with carmine, yellow center. Flower opens flat and is carried on a stem usually 6 inches in height. Blooms early. The bulbs should be planted 6 inches deep. Splendid for naturalizing in shady places; self sows freely. Per doz., $\$ 1.25$; per $100, \$ 8.50$.

\section{EARLY TULIPS}

Useful for potting. Not recommended for outdoor planting as the stems are short.

Per doz. Per 100

Belle Alliance: Single, brilliant scarlet. $\$ .75 \$ \$ 5.50$

Couronne d'Or: Doub!e rich golden yellow.......

Keizerkroon: Single red with broad yellow border

Le Matador: Double scarlet.

Mon Tresor: Single pure yellow

Murillo: Double pink.

Prosperity: Single rose pink

Salvator Rosa: Double deep rosy pink

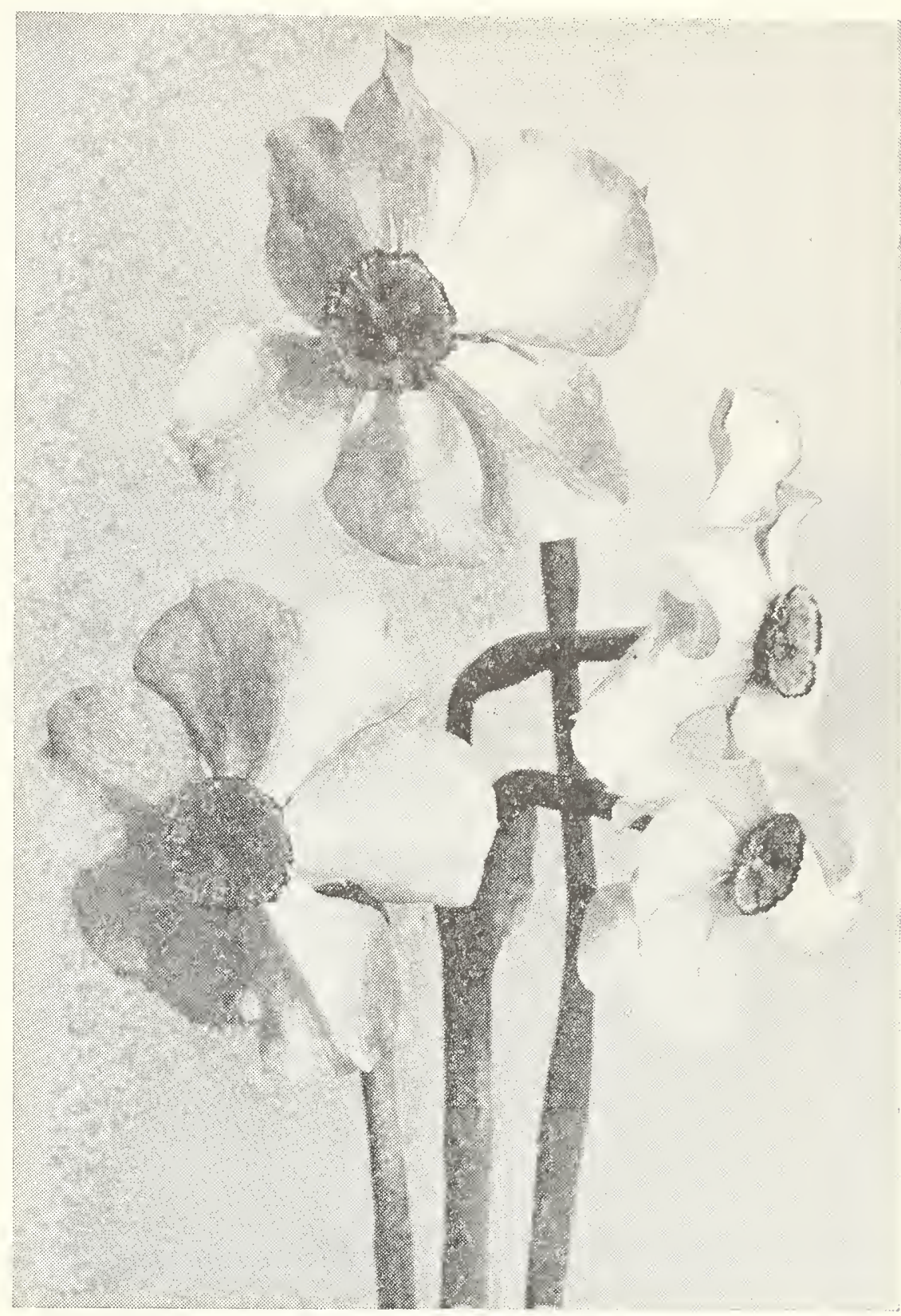

Poeticus Ornatus Narcissus

\section{POET'S NARCISSUS \\ (Postpaid within Fourth Zone)}

Poeticus Recurvus (Pheasant's Eye): Pure white flowers with orange cup, edged with

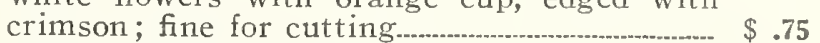

Poeticus Ornatus: Larger than the Poeticus and earlier; beautiful pure white flowers with safiron cup, tinged with scarlet. .75

Poetaz Elvira: Pure white with golden yellow cup, edged orange; free flowering, producing

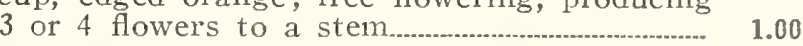

\section{POLYANTHUS NARCISSUS}

(Postpaid within Fourth Zone)

Per doz. Per 100

Paper White Grandiflora: Pure white starshaped blossoms in clusters; very early, free flowering and fragrant. Extra large size.

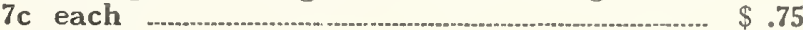

Grand Soleil d'Or: A rich, clear yellow with orange cup; very fragrant and handsome.

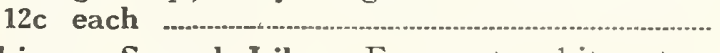

Chinese Sacred Lily: Fragrant white star. shaped blossoms with yellow cups; flower very early and freely. Large bulbs, each $13 \mathrm{c} \quad 1.25$ 


\section{Hyacinths}

Hyacinths are very fragrant and come in a great variety of colors. They make a magnificent display when grown outside in a bed. They are also very satisfactory when grown in pots or in glasses of water. We are listing the single type only, as they are far superior to the double, and more certain to bloom. For outdoor culture, set the bulbs so that the tops will be 3 or 4 inches below the surface and 6 to 10 inches apart. For pot culture use a 4-inch pot for a bulb or a large pot for 2 or 3 bulbs, and leave the tops of the bulbs just above the surface. After potting give a good watering and set away in a cool place and cover with coal ashes or sand until thoroughly rooted, which takes from $\&$ to 10 weeks. During this time do not allow them to become dry. They may then be set in a cool light place until the flower spikes have developed, when they may be placed wherever they are wanted.

\section{NAMED HYACINTHS}

Selected Exhibition bulbs suitable for growing in pots or outside.

\section{(Postpaid within Fourth Zone)}

\section{RED and PINK}

Gigantea: Blush pink Each Per doz. Per 100

Gertrude: Bright rosy red; fine

Koh-i-noor: Large spike of brilliant salmon pink flowers.............................

Lady Derby: Bright rose; very large

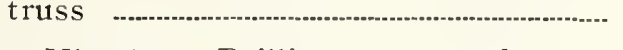

La Victoire: Brilliant rosy red; very

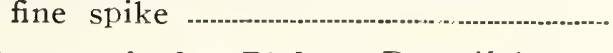

Queen of the Pinks: Beautiful rosy

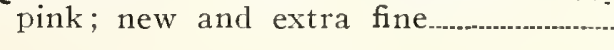

\section{YELLOW}

City of Harlem: Soft yellow; extra large truss ...- Hammer: Creamy yellow;

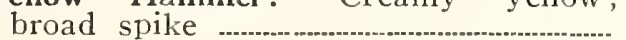

$\begin{array}{rrr}\$ .15 & \$ 1.50 & \$ 10.00 \\ .15 & 1.50 & 10.00 \\ .15 & 1.50 & 10.00 \\ .15 & 1.50 & 10.00 \\ .15 & 1.50 & 10.00 \\ .15 & 1.50 & 10.00\end{array}$

Each Per doz. Per 100 $\$ .15 \$ 1.50 \quad \$ 10.00$ $\begin{array}{lll}.15 & 1.50 & 10.00\end{array}$

\section{BLUE}

Duke of Westminster: Deep, glitiering blue with white center...--..----o--o--o-..

Grand Maitre: Dark porcelain blue,

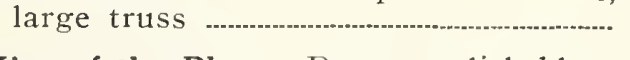

King of the Blues: Deep purplish blue;

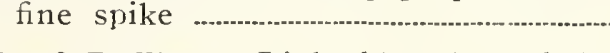

Pearl Brilliant: Light blue, large bells Queen of the Blues: Azure blue; large

\section{WHITE}

Each Per doz. Per 100

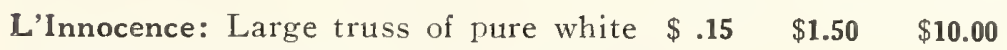
Collection of twelve of any of the above named varieties for.................... $\$ 1.50$

Mixture of all the above named varieties

\section{HYACINTH GLASSES}

Tall type and Bell type; green, 50c each; 60c postpaid within the Fourth Zone.

\section{BEDDING HYACINTHS}

These are good strong bulbs averaging over 6 inches in circumference, and will produce fine flowers.

\section{(Postpaid within Fourth Zone)}

\begin{tabular}{|c|c|c|}
\hline & Per doz. & Per 100 \\
\hline Light blue.------ & $\$ 1.00$ & $\$ 7.0$ \\
\hline g of Blues: Deep blue...... & 1.00 & 7.0 \\
\hline inocence: Pure white. & 1.00 & 7.00 \\
\hline antea: Blush-pink ... & 1.00 & 7.0 \\
\hline n of Pinks: Rosy pink & 1.00 & 7.0 \\
\hline Victoire: Brilliant rosy-red. & 1.00 & 7.0 \\
\hline$y$ of Harlem: Soft yellow....... & 1.00 & 7.00 \\
\hline G & 1.00 & 7.0 \\
\hline
\end{tabular}

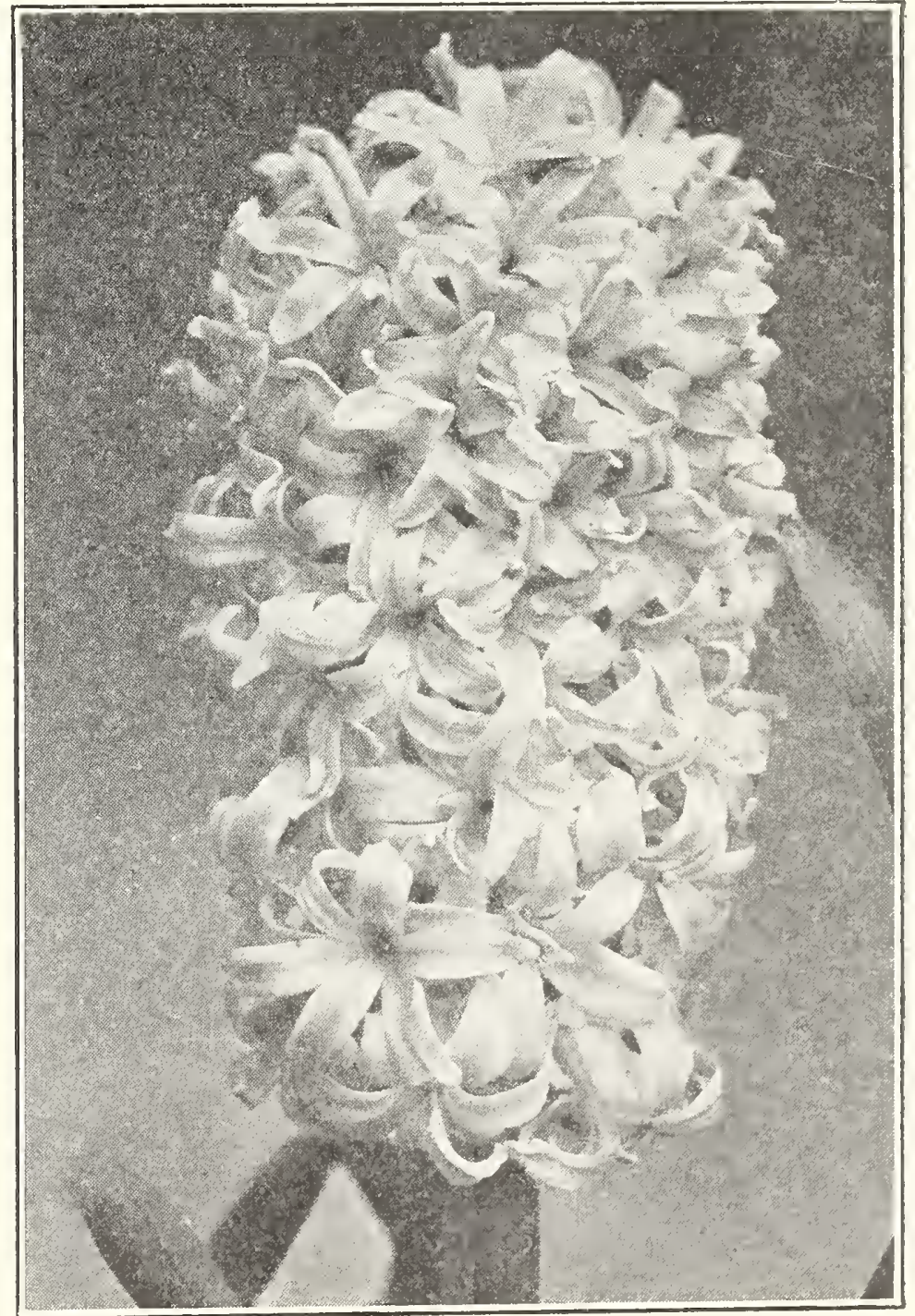

Type of Single Hyacinth 


\section{(All Bulbs Postpaid within Fourth Zone)}

\section{AMARYLLIS}

Belladonna Major: Large beautiful rose-pink trumpet-shaped flowers borne on tall leafless stalks, the leaves appearing after the plant is through flowering. They bloom in August and September. Set the bulbs so that they are barely covered, as deep planting often prevents them from blooming for a long time. Extra large, 20c each; $\$ 2.00$ per doz.

Vittata Hybrids (Hippeastrum): This is pre-eminently a window garden variety producing under simplest conditions, one or two spikes which are crowned with from three to six gigantic blooms, ranging in color from pure white grounds with varied markings of rose or red to self colors as crimson, scarlet, cerise, etc. Cultural leaflet free on request. We can supply large strong bulbs in choicest mixture only. $75 \mathrm{c}$ each; $\$ 7.50$ per doz.

\section{ALSTROMERIA AURANTIACA (Chilian or Peruvian Lily)}

A variety of Chilian Lily, with spikes of lily-like flowers which are orange-yellow, spotted red. Fine as a cut flower, owing to its lasting qualities. They grow 2 feet tall and bloom in July. Set the tubers not less than 6 inches deep. Place some sand around them to afford drainage; usually do not bloom until second season. Each 25c; doz. $\$ 2.50$.

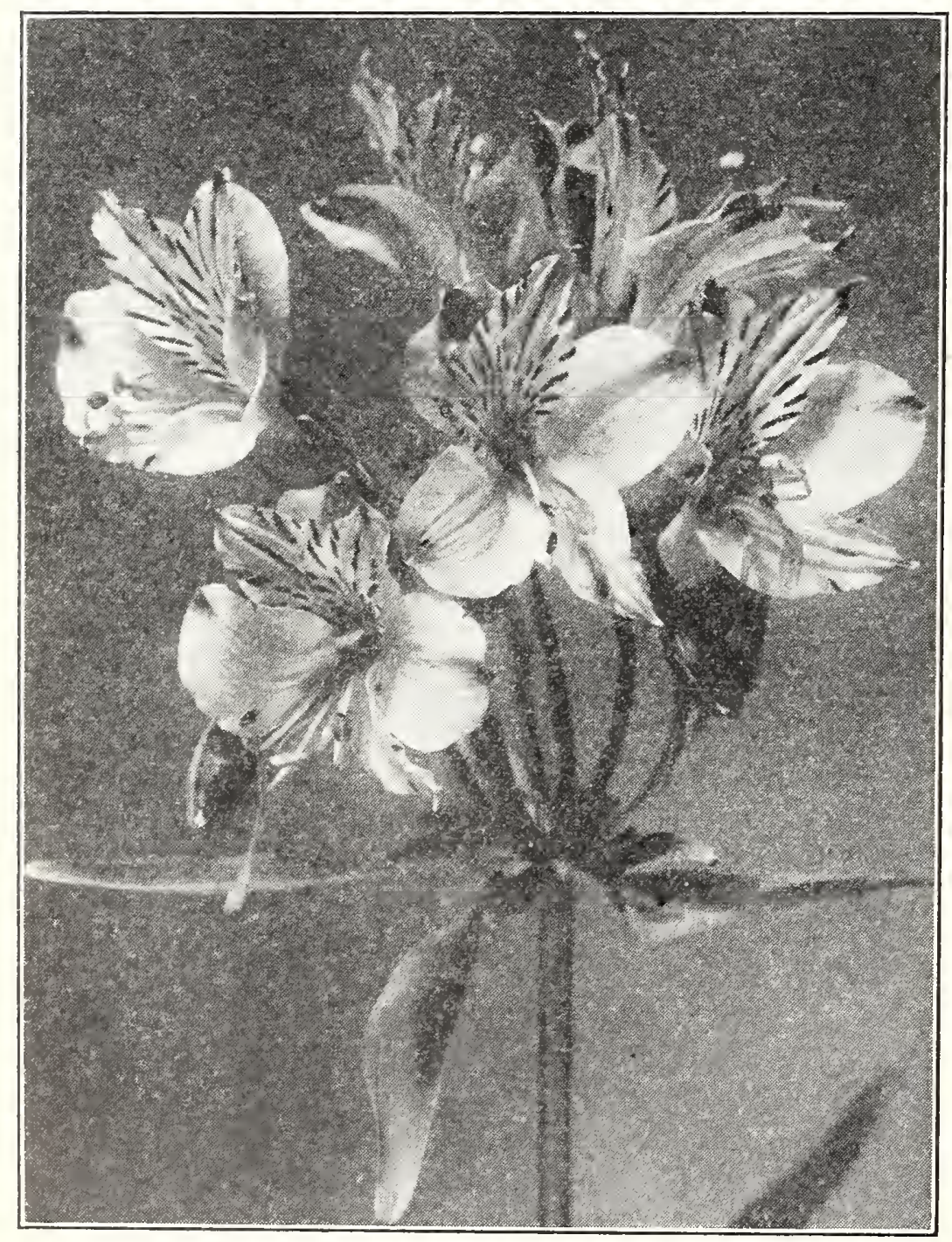

Alstromeria Aurantiaca

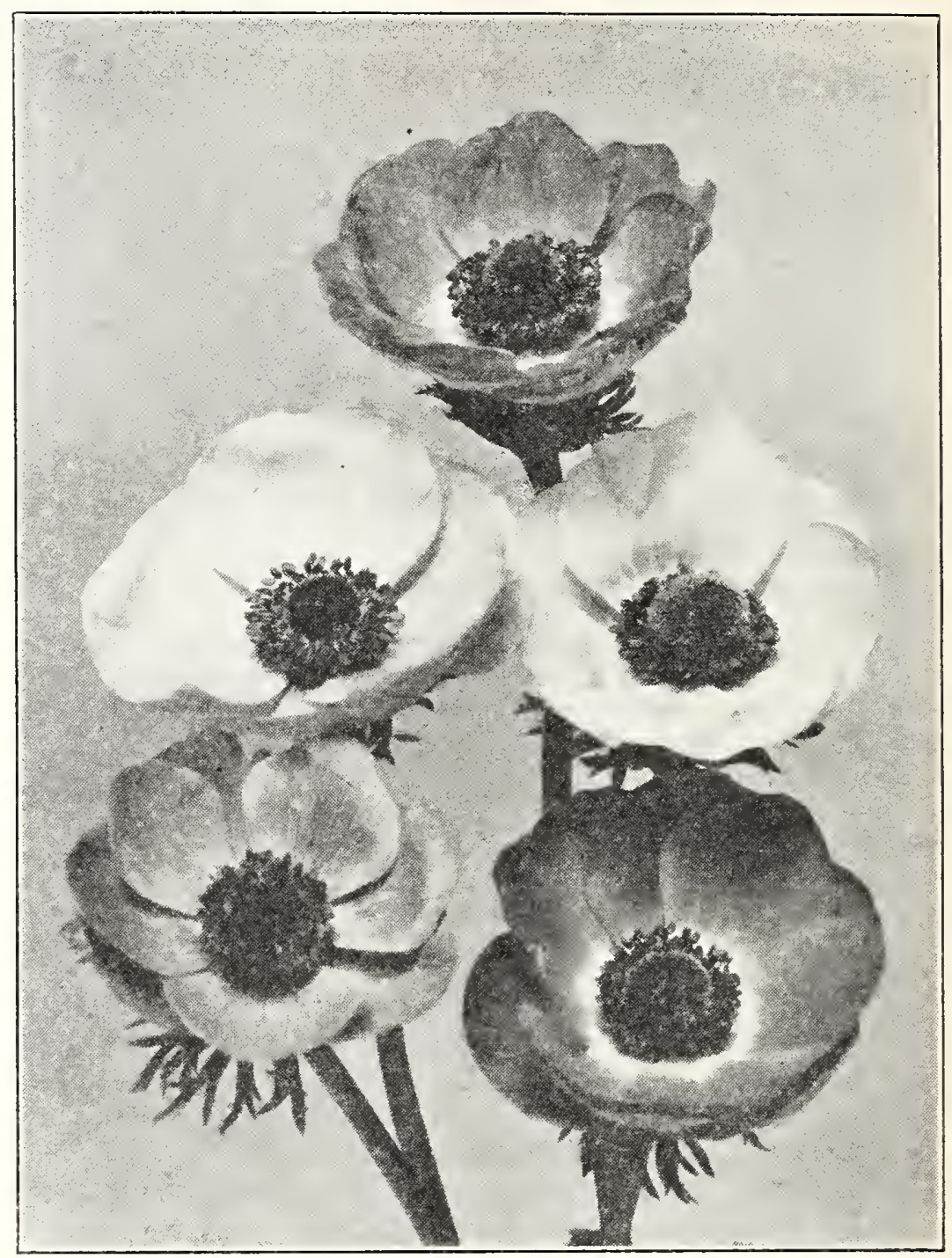

Anemone, Giant Single

\section{ANEMONES (Spring Flowering)}

The blossoms of the single variety resemble Poppies. The flowers are very beautiful and come in a great variety of dazzling colors. They flower early in spring and make a pretty display when planted in a bed or a border.

Set the tops of the bulbs 1 inch below the surface and 6 inches apart. Soak in water overnight before planting. They succeed best in a rich and rather heavy soil.

Caen or Giant Single Mixed: 2 yr. No. 1. 75c per doz.; $\$ 5.00$ per 100.

St. Brigid or Irish Anemones: A distinct strain of graceful habit, producing large flowers, mostly semi-double, with finely divided petals in a large variety of colors. 2 yr. No. 1. 90 c per doz.; $\$ 6.50$ per 100 .

\section{BEGONIA (Tuberous-Rooted)}

(January delivery.)

Splendid pot plants; also useful for bedding outside in partial shade, flowering very profusely.

We cffer Begonias in the following separate colors: Crimson, Salmon, White, Yellow, Pink, and Orange.

Single: All colors, separate or mixed. Eạch 25c; doz. $\$ 2.50$; 6 at dozen rate.

Single Fringed: All colors, separate or mixed. Each 25c; doz. $\$ 2.50 ; 6$ at dozen rate.

Double: All colors, separate or mixed. Each 25c; doz. $\$ 2.50$; 6 at dozen rate.

Lloydi: Of pendulous habit; for hanging baskets and pots. Double Rose, Double Salmon, Double Red. Each 30c; doz. $\$ 3.09 ; 6$ at dozen rate. 


\section{CALADIUM or Elephant's Ear}

\author{
(March 15th delivery)
}

One of the most effective plants for beds or for setting out upon the lawn. When full size the leaf stalks are 6 feet high and the leaves themselves monstrous. Give plenty of water and rich compost.

Caladiums are tender to frost, but come up again next year. Each 30c; doz. $\$ 3.00$.

\section{CALLA}

Yellow Calla Lily (Elliottiana): The true yellow-flowered Calla. The flowers are bright yellow and the foliage dark Calla. The flowers are bright yellow and the foliage dark
green, spotted white. Plant bulbs one inch deep in well drained soil after cold weather is over. Each $25 \mathrm{c}$; doz. $\$ 2.50$. Extra Select, each $35 \mathrm{c}$; doz. $\$ 3.50$. Mammoth, each $50 \mathrm{c}$ doz. $\$ 5.00$.

White Calla Lily: Strong bulbs. Each 15c; doz. \$1.50.

\section{CHIONODOXA (Glory of the Snow)}

Luciliae: A dwarf early spring flowering bulb with brilliant sky-blue flowers with a white center. Grows well in any good garden soil and is excellent for rockeries or borders. Should be planted close together. 40c per doz.; $\$ 2.50$ per 100

\section{CROCUS}

One of the earliest spring flowering bulbs. They are effective when planted in a lawi or in a border 3 or 4 rows deep. Set the tops of the bulbs 2 inches below the surface and 2 to 4 inches apart. For pot culture, plant 6 or 8 bulbs in a pot, 1 inch deep.

Blue and Purple shades, White, Striped, Yellow and Mixed. 35 c per doz.; $\$ 2.50$ per 100 .

Per doz. Per 100

Mont Blanc: Pure white, extra large _................ $\$ .50$ \$3.50

Baron Brunow: Deep purple, extra large...-...- $\quad .50 \quad 3.50$

Yellow: Extra large flower............................... $\quad .50 \quad 3.50$

Sir Walter Scott: White striped lilac, extra

large

Mixture of extra large flowering sorts

\section{DIELYTRA (BLEEDING HEART)}

(Decernber delivery.)

Spectabilis: An old-fashioned favorite. Its long racemes of graceful, heart-shaped pink flowers are very attractive. we any part of the hardy borde $75 \mathrm{c}$; doz. $\$ 7.50$.

\section{ERANTHIS HYEMALIS (Winter Aconite)}

One of the earliest spring flowers; golden yellow buttercup shaped flowers. Foliage remains long after the flower. Suit able in moist situations such as under trees. $40 \mathrm{c}$ per doz.; $\$ 2.50$ per 100 .

\section{GLOXINIA}

Beautiful pot plants for greenhouse culture. The magnificent tube-shaped flowers measure 3 to 4 inches across. They come in several colors and are very prettily spotted and mottled. Royal Purple.

White, edged Pink.

Violet, edged White.

Scarlet.

Red, edged White

Any of the above: Each $40 \mathrm{c}$; doz. $\$ 4.00 ; 6$ at doz. rate

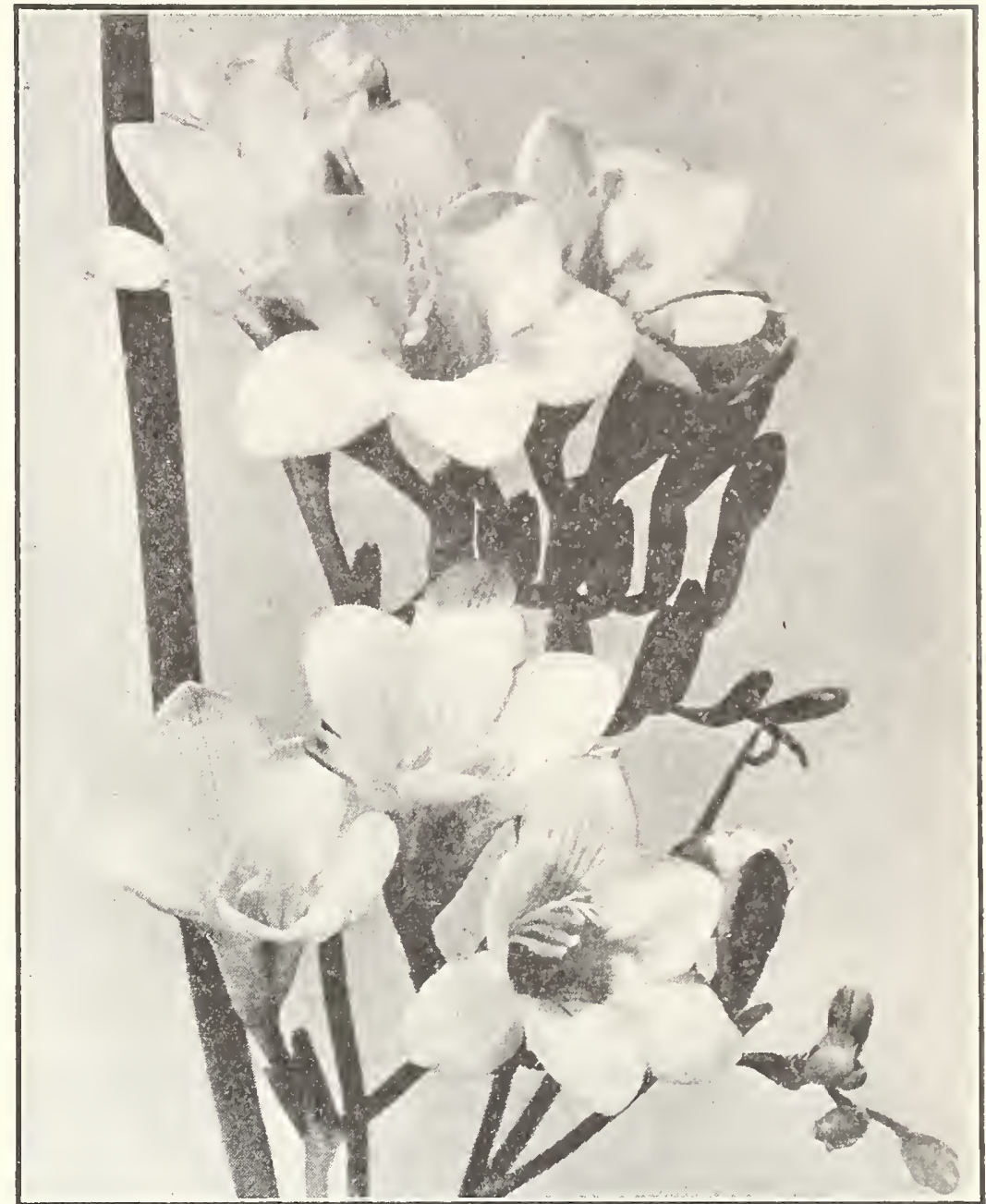

Purity Freesias

\section{FREESIAS}

These can be planted from August to November but early planting is preferable. They bloom in February and March and the flowers which are fragrant are largely used for cutting and last a long time in water.

Set the tops of the bulbs 1 inch below the surface and 3 or 4 inches apart.

Per doz. Per 100

Purity: Finest and purest white variety

Medium size bulbs..................per $1000, \$ 13.50 \quad \$ .25 \quad \$ 1.50$

Extra large size bulbs..._............................... $\quad .50 \quad 3.50$

Amethyst: Amethyst-blue; very fine...-...-.......-.... $\quad .65 \quad 4.50$

Aurora: Yellow suffused with orange.............. $\quad .65 \quad 4.50$

California: Bright golden yellow, extra large.. $\quad .65 \quad 4.50$

Carmencita: Light orange-salmon, medium $\quad .65 \quad 4.50$

General Pershing: Large lavender-pink-_..--...- $\quad .65 \quad 4.50$

Rainbow Mixture: All shades including white $.50 \quad 3.50$

Hallawell's Select Mixture: All shades exclud- $\quad .60 \quad 4.00$

\section{GLADIOLUS (Early Flowering)}

This type of Gladiolus blooms in May. The flowers, borne on long stems, are greatly used for cut flowers.

Per doz. Per 100

Apollo: Orange-salmon; extra good................ $\$ .75 \quad \$ 5.00$

Bride: Pure white............................. $\quad .50 \quad 3.50$

Brilliant: Deep scarlet; extra fine......................... $\quad .75 \quad 5.00$

Peach Blossom: Delicate rosy blush, blotched $.75 \quad 5.00$

Mixture of above sorts 


\section{GLADIOLUS}

The culture of the Gladiolus is one of the easiest. Set the bulbs about 3 inches deep and 7 or 8 inches apart each way. Any good garden soil will make strong plants and good bloom, but for the finest results use manure and plenty of water, After the flowers are past, dig the bulbs up and dry water. Ander cover in the open air for a month and then store them under cover in the open air for a month and then store
in dry soil till next winter, when they may be reset. From December to April are the months in which to plant Gladiolus.

\section{(Postpaid within Fourth Zone)}

Six of a kind at the dozen rate; 50 at the hundred rate.

\section{SELECT NAMED SORTS}

Carmen Sylva: Pure white except for slight violet markings deep in the throat. Very fine. 7c each; 75c per doz.; $\$ 5.00$ per 100 .

Catherine Coleman: Large geranium-pink. One of the outstanding introductions of recent seasons. $10 \mathrm{c}$ each; $\$ 1.00$ per doz.; $\$ 7.00$ per 100 .

Crimson Glow: A brilliant crimson; flowers very large and well placed on a tall spike. 6c each; 60c per doz.; $\$ 4.00$ per 100 .

Dr. F. E. Bennett: Very large, brilliant flame-scarlet. Many open at one time on tall, strong stems. 7c each; 75c per doz.; $\$ 5.00$ per 100 .

Early Sunrise: Red with salmon-yellow throat; very large. $7 c$ each; $75 c$ per doz.; $\$ 5.00$ per 100 .

E. J. Shaylor: Large blooms of a beautiful, clear, deep rosepink. 6c each; 60c per doz.; $\$ 4.00$ per 100 .

Emile Aubrun: A brilliant tone of coppery bronze with large cherry-red blotch; a most unusual shade. 10c each; $\$ 1.00$ per doz.; $\$ 7.00$ per 100 .

Golden Dream: A clear, deep golden yellow, of splendid substance; very tall. Many open at one time. 10c each; $\$ 1.00$ per doz.; $\$ 7.00$ per 100 .

Golden Measure: Deep yellow, with large ruffled flowers well placed on a tall spike. 7c each; 75c per doz.; \$5.00 per 100 .

Halley: Very large flowers of a lovely salmon-pink, lower petals blotched yellow with carmine markings. 6c each; 60c per doz.; $\$ 4.00$ per 100 .

Los Angeles: Shrimp-pink with orange-carmine throat. 6c each; 60c per doz.; $\$ 4.00$ per 100 .

Mrs. Dr. Norton: Pure soft white with tips of petals suffused pink. 6c each; 60c per doz.; $\$ 4.00$ per 100 .

Mrs. Frank Pendleton: A heautiful pink with a conspicuous blood-red blotch in the throat on the lower petals. Flowers are of the largest size and are borne on strong spikes. 6c each; 60c per doz.; $\$ 4.00$ per 100 .

Mrs. F. C. Peters: Orchid-lavender, the throat stained deeply with wine-purple. Many large flowers open at one time on tall, erect spikes. 8c each; 85c per doz.; $\$ 6.00$ per 100 .

Mrs. Leon Douglass: Begonia-rose striped with flame and brilliant scarlet. Lip pale lemon slightly speckled with ruby. Flowers extremely large on extra long spikes. 7c each 75 c per doz.; $\$ 5.00$ per 100 .

Mrs. Joln S. Wood: One of the largest and tallest gladiolus grown; deep salmon-pink shading to coral-pink, flaked scarlet with ruby dots in throat. $10 \mathrm{c}$ each; $\$ 1.00$ per doz.; $\$ 7.00$ per 100 .

Mrs. Van Konynenburg: Beautiful lavender-blue; large and of splendid substance. 15 c each; $\$ 1.50$ per doz.; $\$ 10.00$ per 100 .

Nancy Hanks: Rich apricot to orange-pink with grenarline tongue, vigorous grower. 10c each; $\$ 1.00$ per doz.; $\$ 7.00$ per 100 .

Prince of Wales: Flowers are large and well placed, and the color is a beautiful light salmon. $6 c$ each; $60 c$ per doz. $\$ 4.00$ per 100 .

Purple Glory: Large, ruffled, velvety maroon-red, black blotches, but not in the least purple. 7c each; 75c per doz.; $\$ 5.00$ per 100 .

Rose Ash: A beautiful shade of old rose overlaid and blended with pink. 6c each; 60c per doz.; $\$ 4.00$ per 100 .

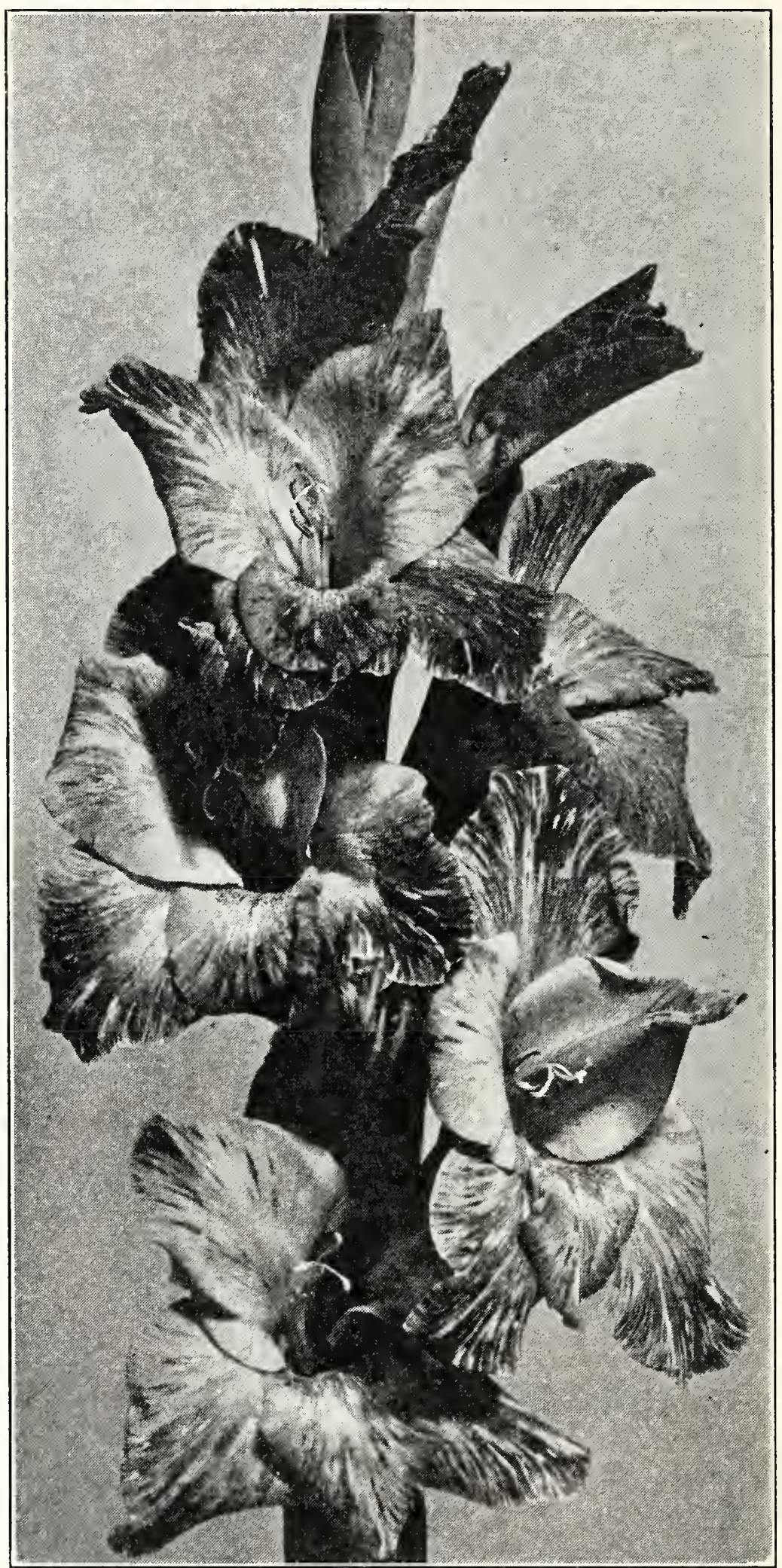

Gladiolus, Prince of Wales

Rosella: Light-rose with a large, starry white blotch in the throat. A strong spike with several large flowers open at one time. 8c each; 85c per doz.; $\$ 6.00$ per 100 .

Saraband: Very large, wide open flower of a rich velvety bordeaux with straw-yellow blotch, feathered bordeaux. Of good substance and a tall grower. 10c each; $\$ 1.00$ per doz.; $\$ 7.00$ per 100 .

Virginia (Scarlet Princeps): Large well-formed flowers of a beautiful shade of glowing scarlet on tall spike. $6 c$ each; 60 c per doz.; $\$ 4.00$ per 100 .

W. H. Phipps: Beautiful La France pink, overlaid light salmon. Lower petals faintly striped and speckled ruby; enormous flowers. 10c each; $\$ 1.00$ per doz.; $\$ 7.00$ per 100 .

Collection of one of each of the above 25 varieties for $\$ 1.75$.

Rainbow Mixture: A mixture of large flowering gladiolus in a good variety of colors. 50c per doz.; $\$ 3.50$ per 100 .

Extra Select Mixture: Made up from best named sorts. $75 \mathrm{c}$ per doz.; $\$ 5.00$ per 100 . 


\section{HARDY IRIS or FLAGS}

This type has beautiful orchid-like flowers and broad foliage, which is evergreen. Very suitable for planting in borders in light shade or sunny places. It requires less care than any other garden flower and thrives well in almost any kind of soil that is well drained. In heavy soil we suggest adding a small amount of lime or wood ashes. Plant 2 inches deep and 15 inches apart.

Transplant about every third year to prevent overcrowding.

\section{GENERAL COLLECTION}

Any of the following varieties. Each $25 \mathrm{c}$; doz. $\$ 2.50 ; 6$ at dozen rate.

"A" Yellow: Deep rich yellow; low growing; early.

Alcazar: Standards lavender-violet: falls velvety minle with bronze veinings; large flower and tall grower; 3 feet.

Amador: Standards lilac; falls slightly deeper shade. Strong grower.

Autocrat: Standards bright clear blue; falls rich dark velvety blue, shading lighter to edges; 30 inches.

Edouard Michel: A large ruffled flower of red-purple; the tallest and best in this color; 3 feet.

Eldorado: A distinct and striking blend of bronze, heliotrope and violet-purple; very foriferous.

Iris King: Standards golden; falls velvety garnet.

Lady Foster: One of the noblest lavender-blue Irises. Flowers unusually large and of excellent substance; 40 inches.

Lent A. Williamson: Standards lavender-violet; falls velvety pansy-violet; large flower of perfect form.

Loreley: Standards light yellow; falls ultramarine-blue, bordered cream; 2 feet.

Mount Penn: Standards bronzy rose; falls rosy red. A general effect of deep rose-pink; 2 feet.

Rita: Clear blue-purple, of good size; vigorous, early and well branched: 3 feet.

Collection of one each of the above 12 sorts for $\$ 2.50$

\section{EXTRA CHOICE COLLECTION}

Any of the following varieties. Each $35 \mathrm{c}$; doz. $\$ 3.50$; 6 at dozen rate.

Clement Desormes: Standards bronzy rose; falls rosy red; 3 feet.

Dream: A lovely crinkled lilac-pink of perfect form and excellent substance.

Gold Imperial: Brilliant chrome-yellow throughout except for the orange beard; rare finish of texture and form.

J. J. Dean: Siandards light violet; falls velvety royal purple; large and tall

Lord of June: Standards palest lavender-blue; falls rich aniline-blue.

Lucida: Light blue; early, prolific and very fragrant; 30 inches.

Madame Cheri: Standards bronzy lavender; falls violetflushed bronze; 42 inches.

Madame Gaudichau: Standards brilliant violet; falls blackish purple; 36 inches.

Magnifica: Standards light violet-blue; falls red-violet; huge Howers; 40 inches.

Medrano: Standards bronzy claret; falls deep velvety crimson; 24 inches.

Prospero: Standards light violet; falls deep violet; 40 inches. Sunset: Standards are like cloth of gold; falls of the same color but suffused blue-violet. A strong grower.

Collection of one each of the above 12 sorts for. $\$ 3.50$

\section{IRIS NOVELTIES}

Frieda Mohr: A gigantic rose toned Iris of perfect form, good texture and brilliant coloring; very stately and beautiful; 42 inches. $\$ 2.00$ each.

William Mohr: A wonderful hybrid; the ground color is pale lilac flushed and beautifully veined violet. A very large flower of fine substance and shape; 20 to 24 inches. $\$ 2.50$ each.
COLLECTION OF NEWER IRIS

Any of the following varieties. Each 50c; doz. $\$ 5.00 ; 6$ at dozen rate.

Ambassadeur: Standards smoky bronze; falls dark velvety maroon.

Asia: Standards nale silvery lavender with golden yellow base; falls rosy lavender, lighter at margins; golden yellow beard; 4 feet.

Glowing Embers: Standards light brownish lavender; falls rich velvety purple with orange beard and conspicuous yellowed center ; 4 feet.

Hidalgo: A very large lavender self of unusually broad sliape; 4 feet.

Rosado: Beautiful, clear soft-pink of unusual size; 42 inches.

Santa Barbara: The finest of the pure lavender-blues; 40 inches.

True Delight: A very lovely white with rose colored veinings free flowering: 3 feet.

Collection of one exch of the above seven sorts for

$\$ 2.85$

\section{IRIS FILIFOLIA}

An early, improved type of Spanish Iris producing extra large flowers on strong stems. Plant the bulbs 4 to 6 inches apart and set the tops 2 to 3 inches below the surface.

Per doz. Per 100

Imperator: Brilliant blue $\$ .65 \$ \$ 4.50$

White Excelsior: White

Yellow Queen: Golden vello $.85-7.00$

Mixture of the above sorts $\quad .75 \quad 5.50$

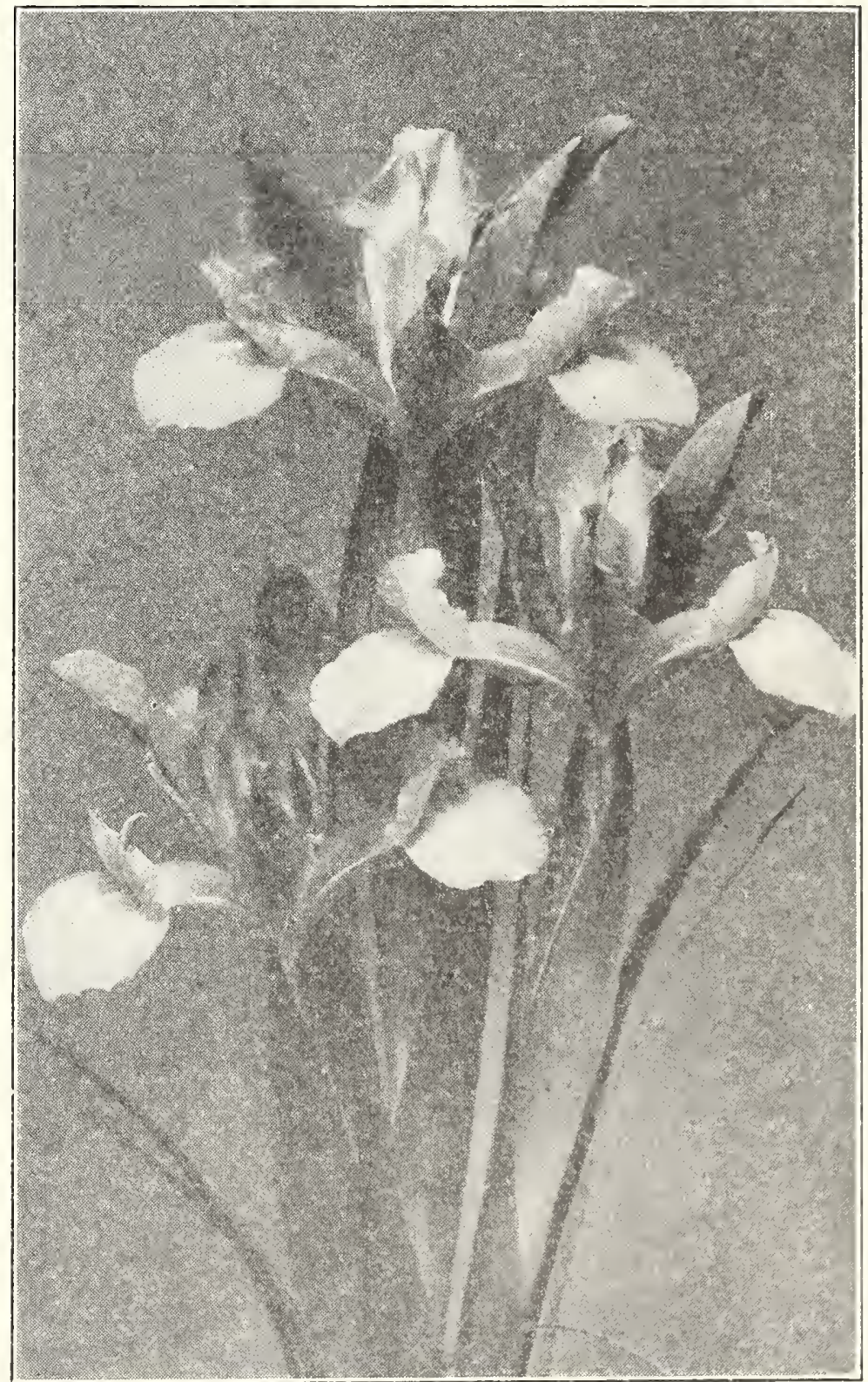

Iris Filifolia 


\section{JAPANESE IRIS}

\section{(Iris Kaempferi)}

This variety of Iris produces the largest and finest flowers in a great variety of colors. They are hardy and do best in partial shade and require plenty of water. They bloom for six weeks during June and July. The flowers measure 8 to 10 inches in diameter and are borne on long stems.

Asama: Bluish-lavender.

Florence: Old rose.

Fukushima: Rose-pink.

Kedar: White, flushed blue.

Nasir Kehl: Deep purple-lavender, flushed white.

Purple Prince: Dark purple-blue.

Tacoma Beauty: Pure white.

Thais: Maroon.

Any of the above varieties, large clumps, each $50 \mathrm{c}$; doz. $\$ 5.00$.

\section{IRIS CRISTATA}

A free flowering sort with evergreen foliage. The small pale-blue flowers are fringed and spotted with orange and are borne in large numbers on 2 to 3 feet branching stems. Requires a damp soil. 25 c each; $\$ 2.50$ per doz.

\section{SIBERIAN IRIS}

This species has narrow foliage and tall, slender stems, with handsome flowers very much like those of the Spanish Iris which are excellent for cut flowers. It forms strong grassy clumps. 3 to 4 feet high.

Each Per doz.

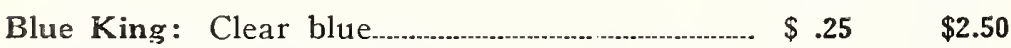

Snow Queen: Ivory white $\ldots$

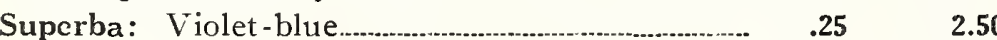

\section{MIDWINTER IRIS (Stylosa)}

The leaves of this species are two feet long and form clumps like our wild Iris; in bloom continuously from fall to spring.

Lilac-blue with grassy evergreen foliage. $\$ .25$

$\$ 2.50$

\section{IRIS SPURIA}

This group has stout, running root stock, erect, handsome leaves 2 to 4 feet tall and fine flowers. The foliage lasts a long time, making them desirable to plant around pools and in the garden they make fine groups.

Aurea: Deep golden yellow; 4 feet

Each Per doz. $\$ .35 \$ 3.50$

\section{IXIAS}

They are much admired for their brilliant colors and graceful flower stalks, which resemble a miniature Gladiolus. They come in several shades and are fine for cutting, lasting several days in water. The bulbs should be planted 1 inch deep and from 4 to 6 inches apart, and for best effect should be in beds or groups of 25 to 100 or more bulbs.

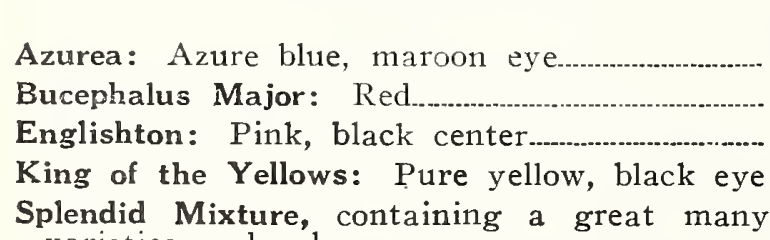

Per doz. Per 100 $\$ .75$ $.75 \quad 500$ .75 .75

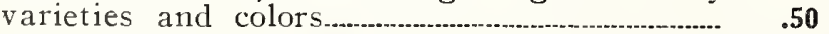

\section{LILY OF THE VALLEY}

(December delivery.)

Suitable for pot culture or outdoors. For outdoor culture they require a loose, rich soil and a moist, shady position. Set so that the tips are slightly above ground and at a distance of three or more inches apart. Outdoor type 75c per doz.; $\$ 5.50$ per 100, Potting and Forcing type, 90c per doz.; $\$ 6.50$ per 100 .

\section{MONTBRETIAS}

\author{
(December delivery)
}

A summer-flowering bulb somewhat resembling a Gladiolus. The flowers come in shades of orange and yellow and are borne on long graceful spikes, and bloom from July to September. Plant several bulbs in a clump about 2 inches deep.

Per doz. Per 100

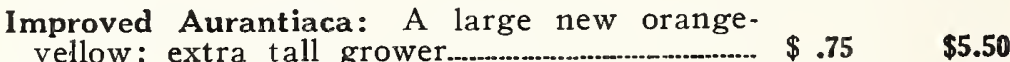

Fire King: Large glowing scarlet-red.............. $\quad .75 \quad 5.50$

\section{MUSCARI}

\section{or GRAPE HYACINTH}

These are dainty little flower spikes bearing curious ballshaped bells in white and blue. Thriving either in partially shaded or sunny locations.

Per doz. Per 100

Azureus: Cambridge blue, flowering in Feb-

Heavenly Blue: Flowers clear deep blue,

changing to lighter blue; very strong grower,

producing much larger spikes than the or-

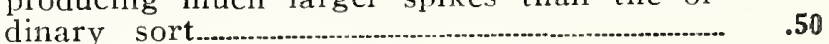

3.00

\section{NERINE SARNIENSIS \\ (Gi1ernsey Lily)}

A handsome autumn flowering greenhouse plant belonging to the Amaryllis family. It flowers from September to November without any foliage and the leaves are developed all winter. About May the leaves die down and the bulbs rest from that time to August. The bright crimson fluted flowers are borne in umbels of 10 to 12 and have a spidery look. The require much root room; they flower best when hard pot bound; these bulbs may remain in a 5 -inch pot for 5 or 6 years. 30c each; $\$ 3.00$ per doz.

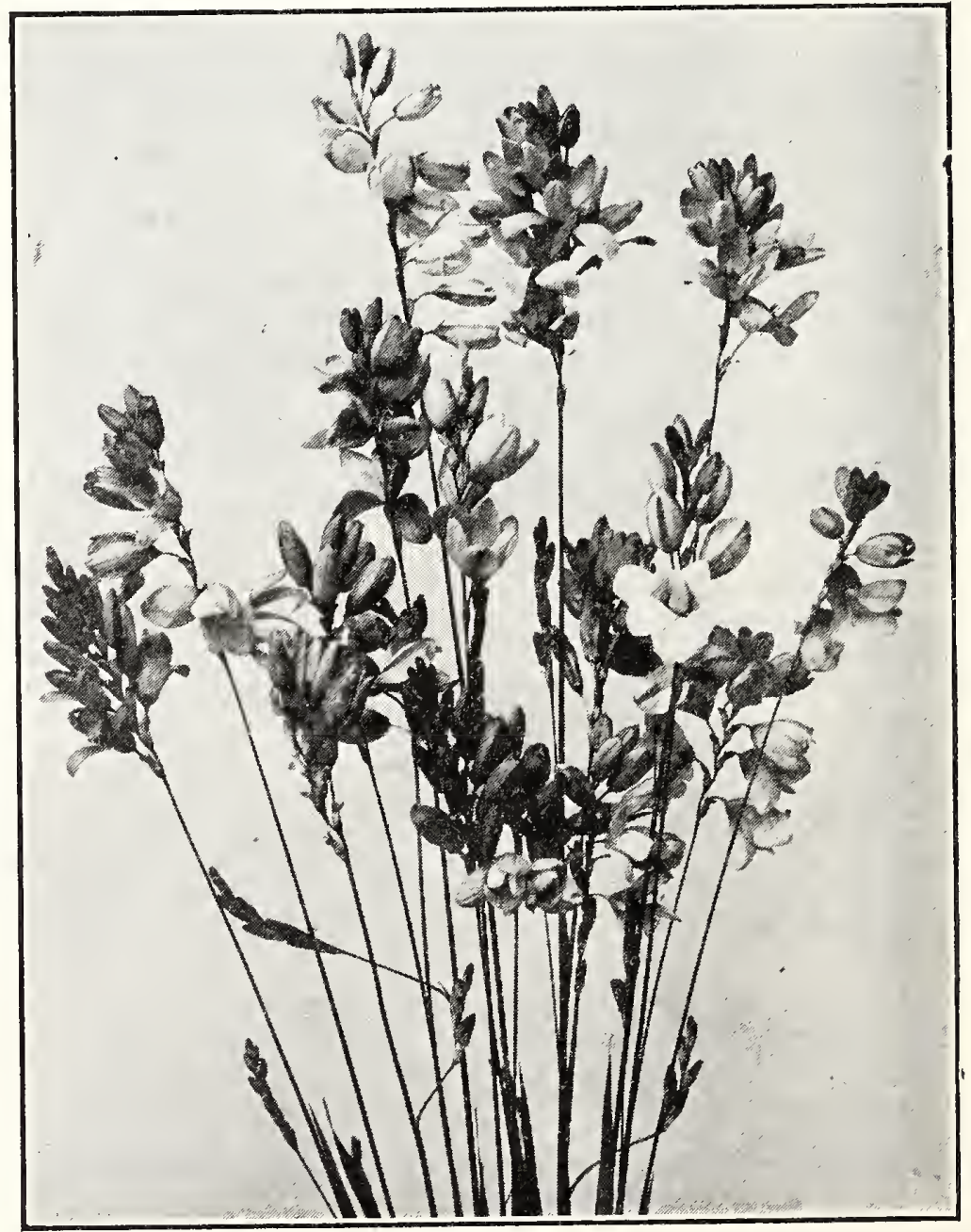

Ixias 


\section{LILIES}

Lilies are benefited by shade about the roots but do not do well with shade about their heads, so should always be planted among fairly dwarf growing shrubs or plants.

The soil for lilies should be a friable loam and should be deeply dug. Sharp sand placed directly under the bulb insures good drainage. Charcoal and sulphur sprinkled about in planting tend to ward off attacks of worms and blue mold.

The bulbs of the following varieties should be planted at least six inches deep and a foot apart, excepting Lilium Candidum, which should be planted rather near the surface; and Lilium Pardalinum three inches deep. Water only lightly until they are well rooted, but liberally when about to bloom; keep free from aphis or green fly at all times.

\section{(November and December delivery.)}

Auratum (Golden Banried Lilv): The grandest of all hardy lilies, with large graceful flowers of an ivory white color, thickly studded with chocolate-crimson spots and a bright gold band through the center of each petal. 25c each; $\$ 2.50$ per doz.; \$17.50 per 100. Extra large, 35c each; $\$ 3.50$ per doz.; $\$ 25.00$ per 100 .

Auratum Platyphyllum: Similar to Auratum, but larger and finer in all respects. Especially noted for its broad, lustrous leaves, which give double attraction. The petals are studded with crimson-chocolate spots. $35 \mathrm{c}$ each; $\$ 3.50$ per doz.; $\$ 25.00$ per 100 . Extra large, 50 c each; $\$ 5.00$ per doz.; $\$ 35.00$ per 100 .

Candidum (St. Joseph or Madonna Lily): A very hardy early flowering lily; the pure white flowers are fragrant and are borne on long stems. The best white lily to plant out of doors. (Order in October, as bulbs must be planted

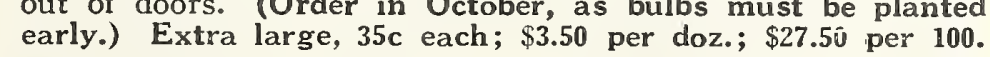

Henryii (the Yellow Speciosum): The flowers are a rich apricot-yellow with a few brown spots; grows 3 to $5 \mathrm{ft}$. high; very hardy and free flowering. Large bulbs, $35 \mathrm{c}$ each; $\$ 3.50$ per doz.; $\$ 25.00$ per 100 .

Humboldti Magnificum: A grand native lily growing usually 4 to 5 feet high with very stout stem and many large orange-red flowers. Spotted with maroon. This species does well in the adobe soil about San Francisco Bay. Bulbs should be planted 4 inches deep. First size bulbs. 50c each; $\$ 5.00$ per doz.

Longiflorum Giganteum (Japanese Faster Lily): A free flowering lily with pure white trumpet-shaped flowers; fine for growing in pots for Easter, and very desirable for outdoor growing in pots for Easter, and very desirable for outdoor
planting. 30c each; $\$ 3.00$ per doz.; $\$ 21.00$ per 100 . Extra planting. $30 \mathrm{c}$ each; $\$ 3.00$ per doz.; $\$ 21.00$ p
large, 50c each; $\$ 5.00$ per doz.; $\$ 35.00$ per 100 .

Pardalinum: The native Tiger or Leopard Lily found growing in the mountains in all parts of California. The flowers are borne on tall stems and are scarlet and yellow spotted with brown. Requires moisture and some shade. 25c each; $\$ 2.50$ per doz.

Regale: A magnificent new hardy lily from China; vigorous; 3 to 5 feet high, bearing one to several handsome white fragrant flowers; slightly shaded pink outside and the lower inner surface primrose-yellow. It seems to thrive in any good, well-drained soil. Strong 30c each; $\$ 3.00$ per doz.; any good, well-drained soil. Strong $30 \mathrm{c}$ each; $\$ 3.00$ per doz.;
$\$ 21.00$ per 100 . Extra large $40 \mathrm{c}$ each; $\$ 4.00$ per doz.; $\$ 30.00$ per 100 .

Speciosum Rubrum (Pink Tiger Lily): A strong, vigorous grower, having stems 3 to 4 feet tall, with bright blossoms, which are white, shaded rose and spotted deep red. 30c each; $\$ 3.00$ per doz.; $\$ 21.00$ per 100 .

Speciosum Rubrum Magnificum: This variety is similar to the Rubrum, but is Jeeper crimson. 30c each; $\$ 3.00$ per doz.; $\$ 21.00$ per 100 .

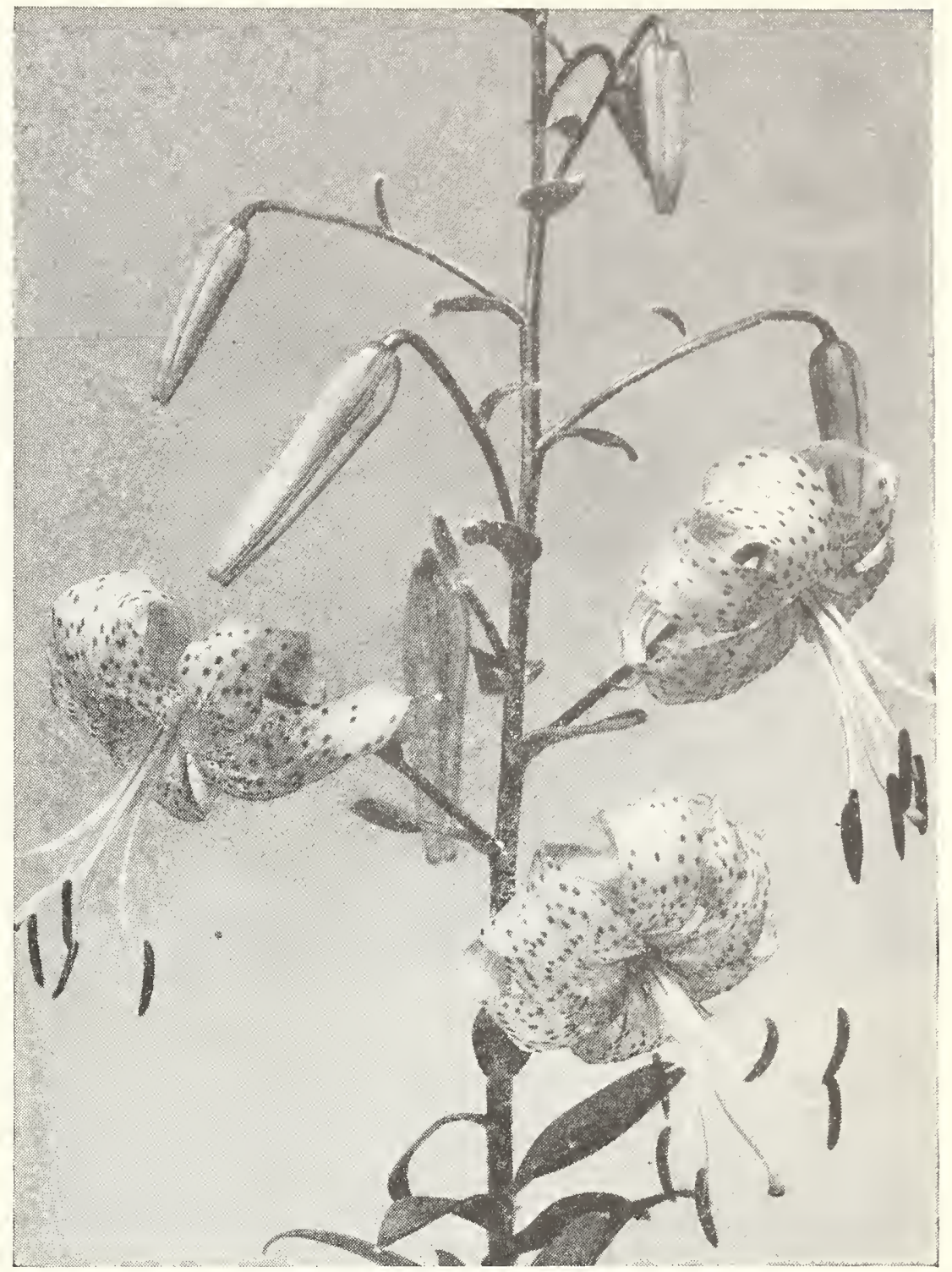

Lilium Tigrinum Giganteum

Tigrinum Giganteum (Improved Tiger Lily): A very hardy and free flowering sort; the blossoms are a bright orange color, spotted black, 25c each; $\$ 2.50$ per doz.; $\$ 17.50$ per 100 .

Umbellatum: One of the earliest lilies, blooming in June. Very free flowering with large umbellate heads of orangered. Height 2 feet. Plant 8 inches deep. Large 35c each; $\$ 3.50$ per doz.

\section{ORNITHOGALUM}

Arabicum (Star of Bethlehem): Beautiful variety, throwing up a tall spike bearing numerous large, milk-white, starshaped flowers, with a black center, and having a distinct aromatic perfume. They are the easiest culture. 8c each; 85 c per doz.; $\$ 6.00$ per 100 .

\section{HERBACEOUS PEONIES}

Plant them in deep rich soil, setting the roots so that the crowns are covered with two inches of earth. If planted too deep they are not likely to bloom freely.

\section{(November delivery)}

Strong Clumps: In separate colors or assorted, 60 c each; $\$ 6.00$ per doz.

Albert Crousse: Large shell-pink.

Claire Dubois: Silvery satiny pink.

Edulis Superba: Deep rose pink, shading lighter.

Felix Crousse: Rich, brilliant ruby-red.

Festiva Maxima: Pure white.

Madame Calot: White flushed, delicate pink; most fragrant of all Pennies and extremely free blooming. 


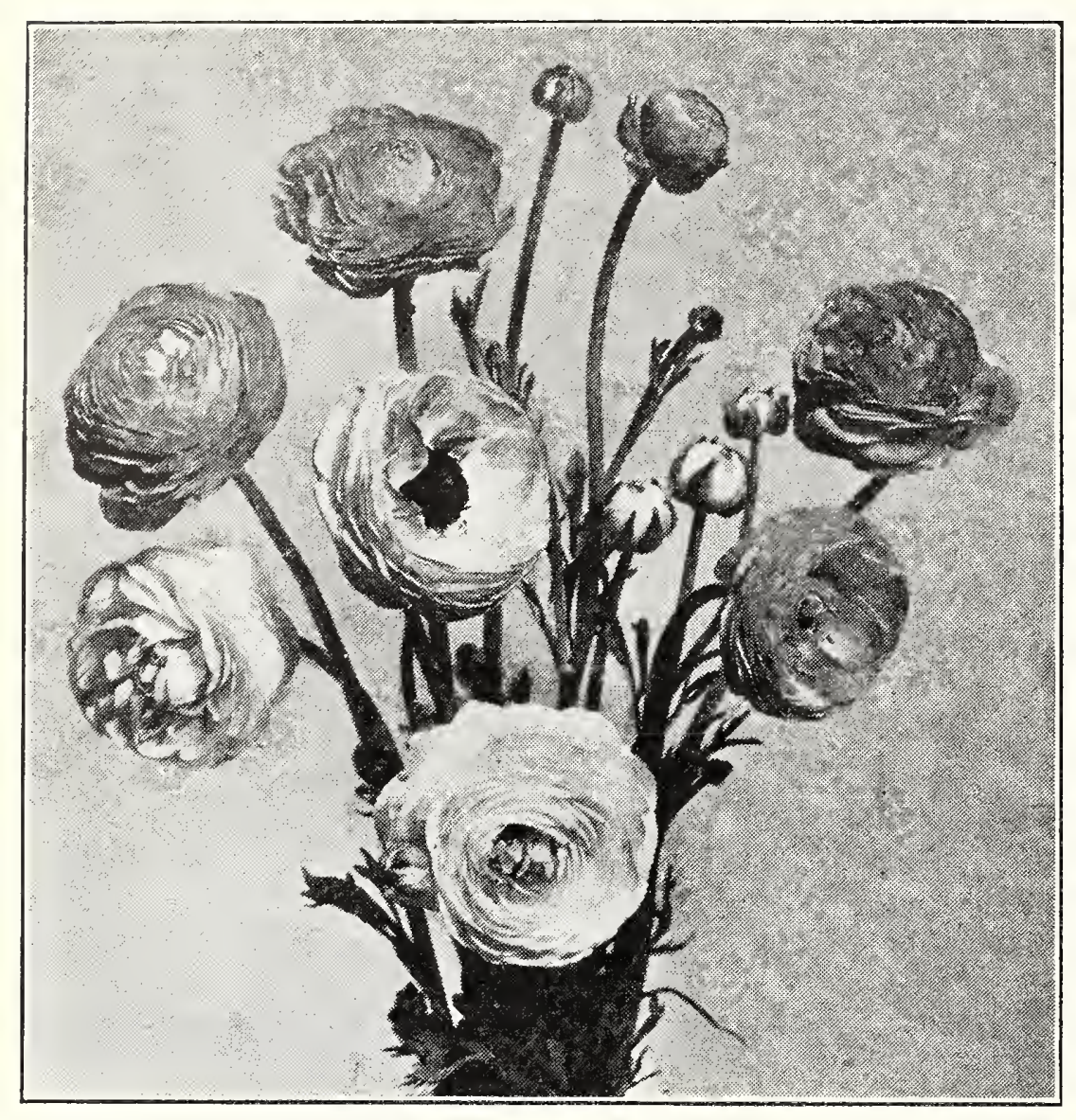

Ranunculus

\section{RANUNCULUS}

Attractive spring flowering bulbs producing flowers on stems about 9 inches high. To insure good results it is essential to grow them in a surny situation and in loose, light, welldrained soil that is kept at an even moisture. If the soil is allowed to become water-logged or dry they will not succeed. After soaking the bulbs for one or two hours plant 1 inch deep and 6 inches apart, placing the finger-like projections downward. Early planting is not recommended. November is the best month.

Per doz. Per 100 No. 1 ..... $\$ .75 \quad \$ 5.00$ Good Mixture _._.

\section{SCILLA or WOOD HYACINTH}

Charming bell-șhaped flowers that do well inder trees or in other shady situations. Bloom very early; suitable for edgings and borders. Plant 3 inches deep and 4 to 6 inches apart.

Campanulata Alba: Pure white bells, 12 in..... $\begin{gathered}\text { Per doz. Per } 100 \\ \$ \mathbf{5 0}\end{gathered}$

Campanulata Blue: Porcelain-blue, 15 in

Campanulata Rosea: Lavender-pink, 15 in....... $\quad .75 \quad 5.00$

Campanulata Mixed ............................................. $\quad .60$

Sibirica (Blue Squill): One of the prettiest early spring-blooming bulbs, with sprays of exquisite rich blue flowers. Height 4 inches

Peruviana or Clusii: Produces a large, broad based pyramidal spike of many bright blue flowers, 8 to 12 inches tall. Desirable for pot culture or planting in the garden....each, 30c

\section{SNOWDROPS}

Universal favorites which flower very early. Plant 2 inches deep and 2 to 3 inches apart.

Single Flowering: 50c per doz.; $\$ 3.50$ per 100 . Double Flowering: $75 \mathrm{c}$ per doz.; $\$ 5.50$ per 100 .

\section{SPRING SNOWFLAKES}

These are similar to Snowdrops but of stronger growth. The flowers are white, tipped with green and are borne on stems 1 to 2 feet high.

50c per doz.; $\$ 3.50$ per 100 .

\section{SPARAXIS}

Beautiful flowers borne on long, graceful spikes. The colors are of the most pleasing combinations and of the brightest shades. They are tigered, blotched, spotted, streaked and flushed in the most diverse and pleasing manner. Plant bulbs 2 inches deep and 3 or more inches apart.

All colors mixed. 50c per doz.; $\$ 3.50$ per 100 .

\section{SPIRAEA (Astilbe)}

(November delivery.)

While these can be used for outdoor planting, where they will bloom during the summer, their great value lies in their ease of culture as a house plant. $\begin{array}{lrr} & \text { Each } & \text { Per doz. } \\ \text { Gladstone: Finest white, very large flowers...... } \$ .60 & \$ 6.00\end{array}$ Queen Alexandra: Beautiful pink; strong

grower and free bloomer. When grown in-

doors it should be kept cool when flowers

are developing. This is necessary to bring

are the delicate coloring necessary to bring out the delicate colori
Rubens: Deep rosy red.

\section{TIGRIDIA (Tiger Flower)}

\author{
(December delivery)
}

Gorgeousiy colored summer flowering bulbs. The blossoms are short-lived but are produced continuously, during the sunimer. Plant 2 to 3 inches deep and 4 to 8 inches apart. Place sand under the bulb to afford drainage and plant in a sunny position.

Red: 25c each; $\$ 2.50$ per dozen.

Yellow: 25c each; $\$ 2.50$ per dozen.

\section{TRITELEIA UNIFLORA}

"Spring Star Flower." A charming little plant growing only a few inches high and covering the ground with sky-blue, star-shaped flowers. Fine for massing in beds and borders. Plant 2 inches deep and 3 inches apart.

50c per doz.; $\$ 3.50$ per 100 .

\section{TRITONIA CROCATA}

Attractive orange-red flowers about 2 inches across with a transparent blotch at the base of each petal. One foot tall; bloom in May. Plant bulbs 2 inches deep and 3 inches apart. 50c per doz.; $\$ 3.75$ per 100 .

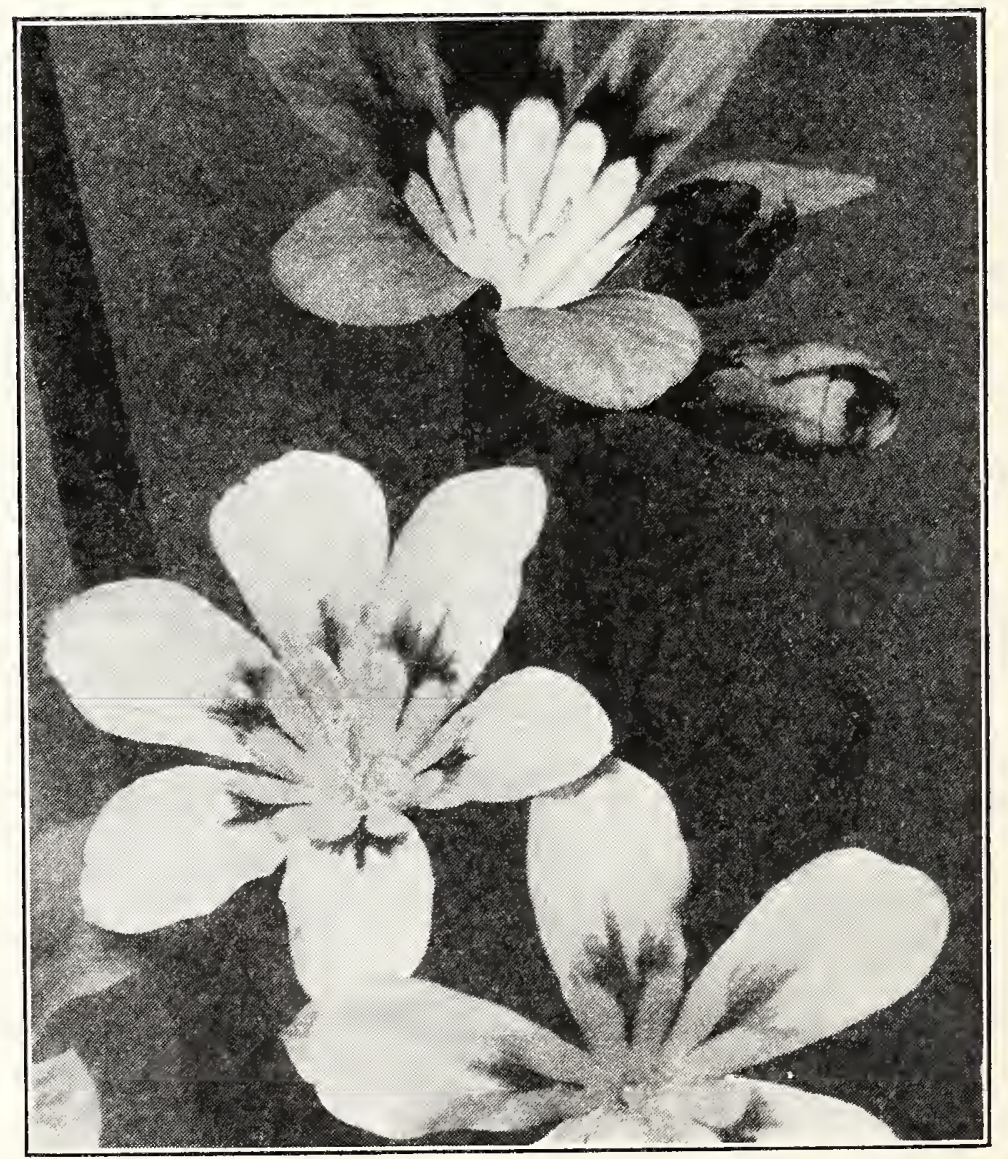

Sparaxis 


\section{TUBEROSES}

(March 15th delivery)

The flowers grow on stems 18 inches high, each stem bearing about a dozen flowers. They are pure white, wax-like, and very fragrant. Plant outdoors when all danger of frost is over. Cover the bulbs about an inch with fine light soil. Double Dwarf Pearl: Extra selected bulbs, 90c per doz.; $\$ 6.50$ for 100 .

\section{WATSONIA}

Watsonias are similar to the Gladiolus and bloom from June until August. The spikes grow 3 to 4 feet tall and bear about 1 dozen flowers, which are $21 / 2$ to 3 inches long and about 2 inches across. They bloom freely and thrive best in a sunny situation. Set the bulbs 3 inches deep and 8 inches apart. Per doz. Per 100

Andernei: Large spikes of pure white flowers $\$ .50 \quad \$ 3.50$

\section{NEW HYBRID WATSONIAS}

The bulbs vary considerably in size, according to the varieties, some of the best sorts having quite small bulbs. Ed. Sturtevant: Brilliant orange.

Eunice: Flesh color tinted salmon.

Fanny Lyon: Apricot-buff, flowers large, on tall, graceful stems.

J. J. Dean: Rose-pink with deeper shadings.

Any of the above 25c each; $\$ 2.50$ per doz.; $\$ 17.50$ per 100 .

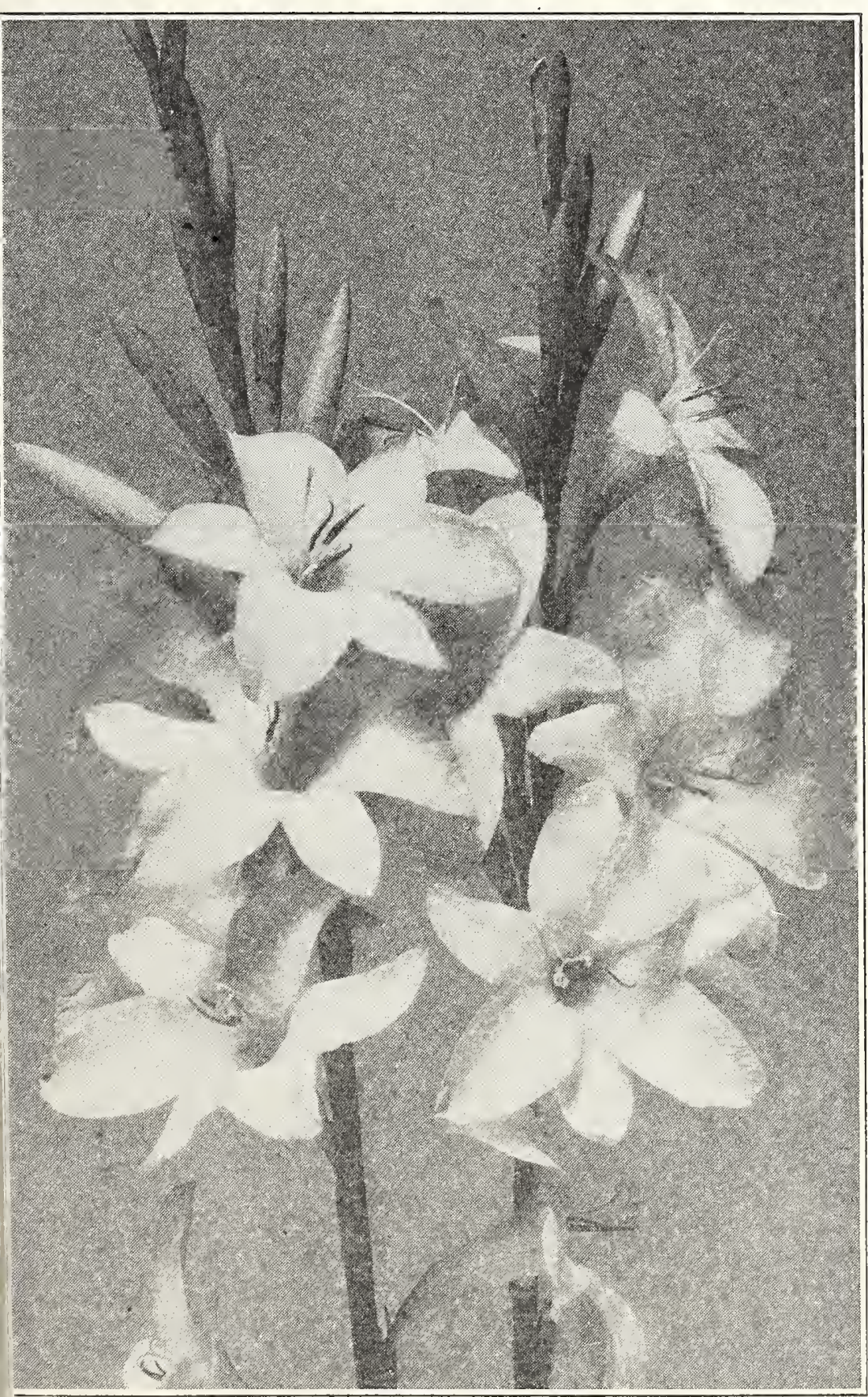

Watsonia, New Hybrids

\section{PANSIES}

(For cultural directions see our general catalog.)

Geneva Giants: The flowers are of gigantic size and perfectly round and average 3 inches in diameter. The colors vary in reddish maroon, bronze, blue, p11rple and yellow; frequently with new color combinations_._. Pkt. of 375 seeds $\$ 1.00$

Hallawell's Prize Strain: This is a mixture of the giant-flowered varieties, all the plain colors, faced sorts, ruffled edged, and rare sorts; also the varieties exquisitely marbled, striped and blotcher

Pkt. of 500 seeds

Steele's Special Mixture: A fine mixture of choice

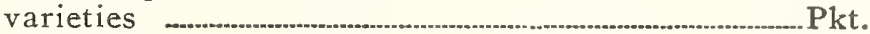

Giant Masterpiece: These pansies have a combination of rich velvety colors and attractive ruffled petals......

Giant Parisian Mixed: A large flowering type of Trimardeau pansies; the top petals are larger than the three lower ones and are beautifully marked; very

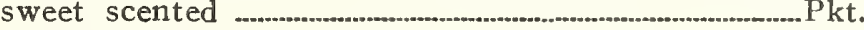

Bedding Mixed: A mixture of various colors.........Pkt.

.10

GIANT FLOWERED VARIETIES

(In separate colors.)

Giant Adonis: light blue.

Giant Black.

Giant Bronze: bronze shades.

Giant Cardinal: brilliant red.

Giant Emperor William: dark navy blue.

Giant Fire King: golden yellow, upper petals crimson.

Giant Golden Queen: pure golden yellow.

Giant Lord Beaconsfield: lavender, heliotrope and purple.

Giant Prince Henry: rich dark blue.

Giant Snowflake: pure white.

Giant Victoria: wine red.

Giant Yellow King: golden yellow with dark eye.

$15 \mathrm{c}$ per pkt. Collection of 6 of any of the above sorts, 75c. Tufted Pansies: see Viola.

\section{LAWN GRASSES}

Chewing's Fescue: Forms a close, lasting turf, succeeding well even under poor conditions. It is used extensively in lawn and putting green mixtures. Lb., 65c; $10 \mathrm{lbs}$., $\$ 6.00$.

Hallawell's Evergreen Lawn Mixture: A mixture of several deep green grasses which makes a thick, sturdy lawn, remaining green both summer and winter. It is especially adapted for heavy or black soils. Lb., 60c; 10 lbs., $\$ 5.50$.

Kentucky Blue Grass: Fancy; extra clean; the most popular grass for lawns. It is dark green and of dense growing habit, making a beautiful turf in a heavy or black soil. Lb., 50c; 10 lbs., $\$ 4.50$.

Pacific Rye Grass (Genuine Pacey's Rye Grass): This grass is similar to the Australian Rye Grass, but has a finer lea and is longer lived. Use one pound to 100 square feet. Lb., 35c; 10 lbs. $\$ 3.00$.

Park Lawn Mixture (formerly sold under the name of Golden Gale Lawn Mixture). This mixture of hardy grasses contains a little white clover and forms a thick, strong turf that will stand hard usage. Lb., 50c; 5 lbs., $\$ 2.25$; 10 lbs., $\$ 4.00$.

Perennial or Australian Rye Grass: A very vigorous, quickgrowing lawn grass, but a little coarse. Very satisfactory for lawns in San Francisco. Best grass for sandy soils. Use one pound to 100 square feet. Lb., 30c; 10 lbs., $\$ 2.50$.

Red Top Grass: Gives a quick effect and succeeds on all soils, though doing best on moist soils. Should be in all lawn mixtures. Lb., 45c; 10 lbs., $\$ 4.00$.

White Clover: Of dwarf habit with creeping stems, rooting at joints, on which account it makes an excellent turf that stands constant tramping. Planted for a lawn either alone or in mixture with grass seed. Use one pound to 300 square feet. Lb., 75c; 10 lbs., $\$ 6.50$. 


\section{Sweet Peas}

\section{SPENCER or ORCHID FLOWERED SWEET PEAS}

The finest type of Sweet Pea. The blossoms are large and very wavy, with long stems, generally having four blossoms to the stem.

Austin Frederick Improved: Giant lavender

Per pkt. Per oz.

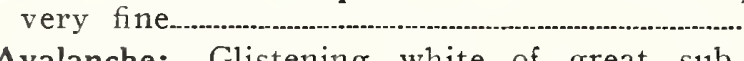

Avalanche: Glistening white of great sub-

Bonfire: Cherry-pink with cream wings............

Brilliant Rose: Bright rose

Carmelita: Delicate yet warm, light rose-pink

Charming: Bright-glowing rose with salmon

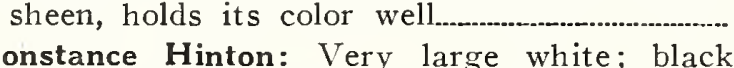

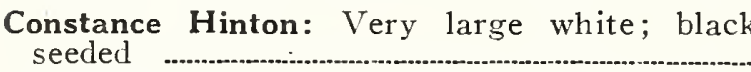

Crimson King. Pure rich deep crimson; purer crimson and deeper tone than King Edward Spencer; the finest of all reds.

Daffodil: Large, deep primrose; black seeded

Del Monte: Rich salmon-cerise-pink................

Fortune: Rich dark blue.

Flamingo: Brilliant orange-scarlet shaded cerise

$\$ .10$

George Shawyer: Giant salmon-rose................ shaded when in bloom

Grenadier: Bright geranium-red...........................

Hawlmark Pink: A most beautiful shade of rich rose-pink, deeply flushed and shaded with salmon. A vigorous grower and exception-

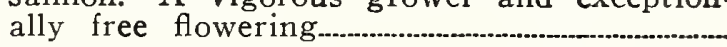

Hercules. Giant bright pink of excellent form

Huntsman: Brilliant scarlet, sunproof and of

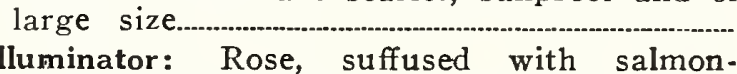

Illuminator: Rose, suffused with salmon
orange; a grand variety of large size and

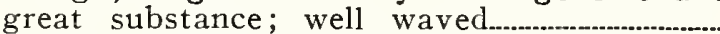

King White: Pure white

Magnet: Bright cream-pink

Mary Pickford: Beautiful, dainty cream-pink with a faint suffusion of salmon......................

Miss California: A distinct shade of salmon and cream-pink: the large fluted flowers are borne on long, stout stems...

Mrs. Tom Jones: Bright delphinium-blue; the flowers are very large, beautifully waved and

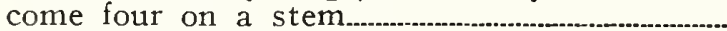

Olympia: Deep rich purple

Picture: Giant flesh-pink suffused creamy

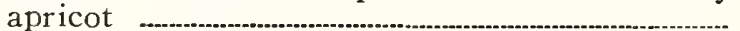

Pinkie: Giant flowered clear deep pink.................

Powerscourt: Large, pure lavender, of ex-

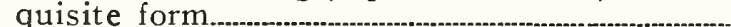

Reflection: Rich, clear blue, of large size and

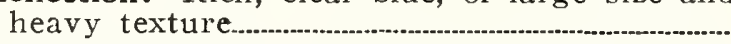

Renown: Large, clear carmine-rose

R. F. Felton: Rich pinkish lavender of im. mense size

Royal Pink: A perfect blend of shrimp-pink

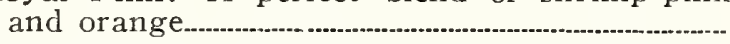

Royal Purple: Rich royal purple; a fine and distinct variety
.10

.10

.10

.10

.10

.10

.10

.10

.10

.10

.10

.10

.10

$\$ .30$

.30

.30

.30

.30

.30

.30

.30

.33

.30

.30

.30

.30

.10

.10

.10

.10

.10

.10

.10

.10

.10

.10

.10

.10

.10

.10

10

.10

.10

.10

.10

.10

.30

30

.30

.30

.30

.30

.30

.30

.30

.30

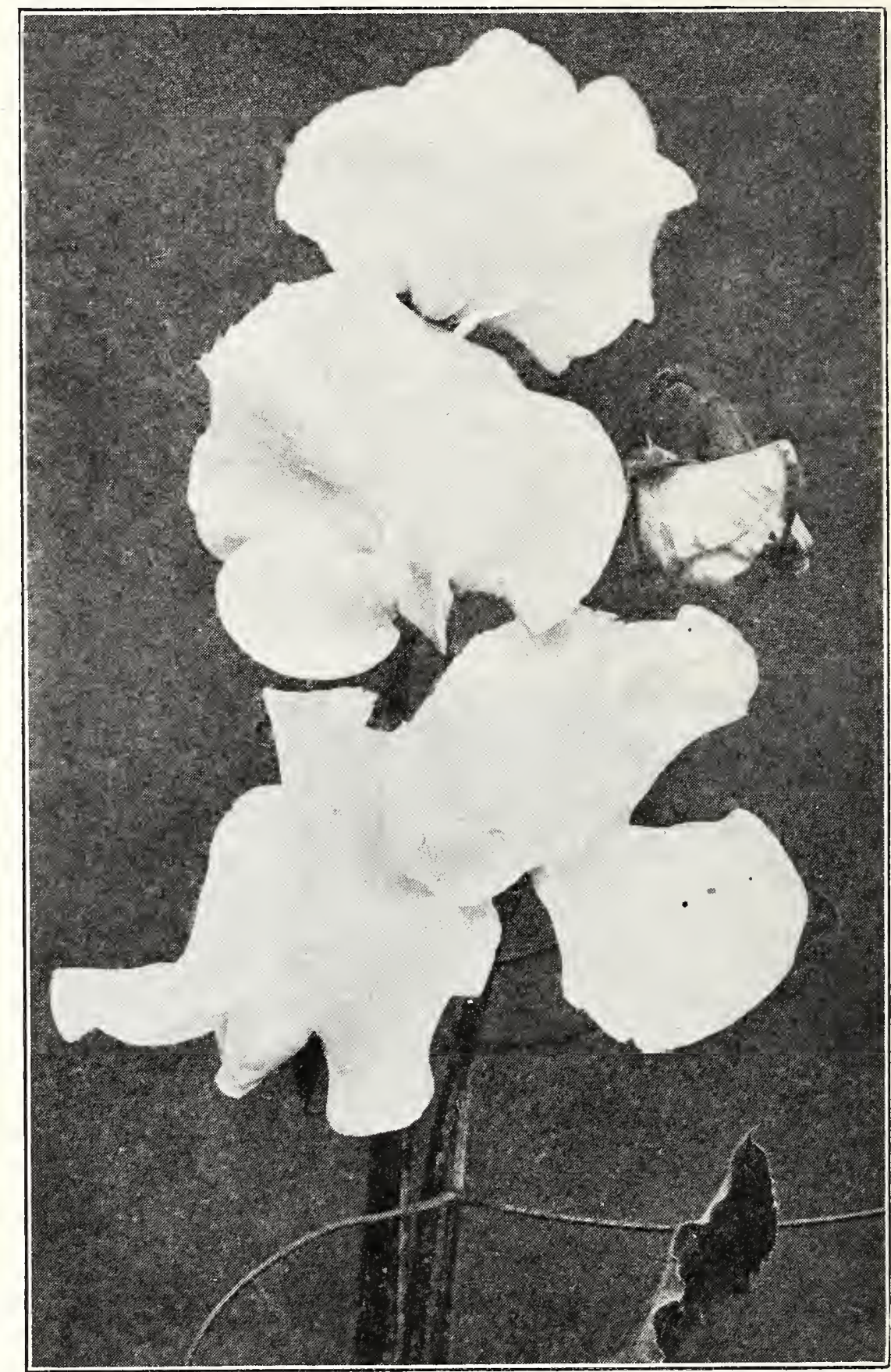

Spencer or Orchid Flowered Sweet Peas

\section{STIM-U-GERM}

A nitrogen gathering bacteria for inoculating Sweet Peas and Garden Peas, garden size, 25c, postpaid.
Per pkt. Per oz.

Royal Salute: A most brilliant deep scarletRoyal Scot: A true brilliant scarlet; does not fade or burn in the hottest sunshine..............

Royal Sovereign: Brilliant orange; should be

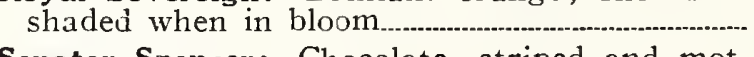

Senator Spencer: Chocolate, striped and mottled on ivory white.

Splendour: Reddish maroon...

Supreme: Yery large, pale pink

Sunset: Rich rose with amber ground; quite distinct

Warrior: Rich chocolate-maroon, flushed with bronze; great form and size....................................... Wembley: Lavender suffused plumbago-blue..

What Joy: Primrose, shading to cream ........Youth: Large pure white with margin of clear pink; developed especially for its fragrance. Superb Collection of 15 sorts for $\$ 1.00$. $\$ .10 \$ .30$ 


\section{Spencer Sweet Peas ${ }_{1}$ Continued}

\section{NOVELTIES IN SPENCER FLOWERED SWEET PEAS}

Bon-Bon: Rich pink with a shading of amber; of large size Rosie: Giant flowered rose-pink; of heavy texture and and heavy texture. Pkt. of 25 seeds $25 \mathrm{c}$.

borne on long stout stems. Pkt. of 25 seeds $25 \mathrm{c}$.

\section{HALLA WELL'S SPENCER MIXTURE}

This mixture is a beautiful blend of the best varieties of Spencers in the proper proportion, and includes all the very latest novelties. Pkt., $10 \mathrm{c}$; 0z. $25 \mathrm{c}$; $\mathrm{I} / 4 \mathrm{lb} ., 75 \mathrm{c}$; pound, $\$ 2.50$.

\section{EARLY LONG SEASON WINTER FLOWERING SPENCER SWEET PEAS}

These varieties have the large ruffled blossoms of the Spencer type and the early flowering habit of the Winter Sweet Peas. They will commence flowering from four to six weeks earlier than the regular Spencer type and remain in bloom for a long season. Especially adapted for the Hawaiian Islands and other tropical countries.

\begin{tabular}{|c|c|c|c|c|c|}
\hline & er pkt. & er oz. & & er pkt. & Per oz. \\
\hline Early All White: Pure white & $\$ .10$ & $\$ .60$ & Early Imperial Pink: Large clear pink & $\$ .10$ & $\$ .60$ \\
\hline 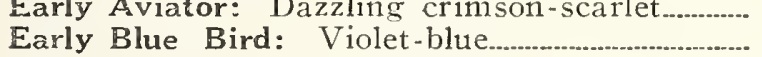 & $\begin{array}{l}.10 \\
.10\end{array}$ & $\begin{array}{l}.60 \\
.60\end{array}$ & 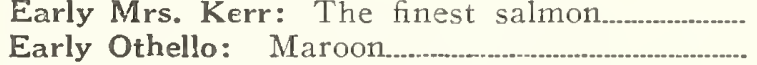 & .10 & .60 \\
\hline Early Cream: Deep cream & .10 & .60 & Early Rose Charm: Large bright rose...... & .10 & .60 \\
\hline Early Fair Maid: Blush pink, suffused salmon & .10 & .60 & Early Rose Dore: Rose-pink, suffused orange & .10 & .60 \\
\hline Early Glitters: Bright fiery orange standard & & & Early True Blue: A charming shade of blue...- & .10 & .69 \\
\hline 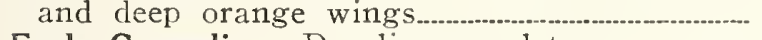 & .10 & .60 & Early Valencia: Sunproof orange, long stems & .15 & .75 \\
\hline $\begin{array}{l}\text { Early Grenadier: Dazzling scarlet } \\
\text { Early Harmony: Clear lavender; of very vigor- }\end{array}$ & .15 & .75 & Early Yarrawa: Bright rose-pink with light & & \\
\hline pit - & .10 & .60 & deep rose-pink.. & & \\
\hline 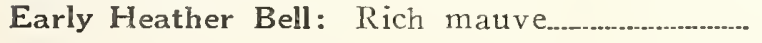 & .10 & .60 & 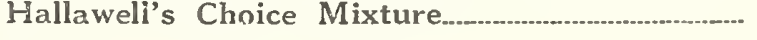 & .10 & \\
\hline
\end{tabular}

\section{EARLY FLOWERING SWEET PEA COLLECTIONS}

No. 1 Collection contains one packet each of Early Aviator, Early All White, Early Glitters, Early Zvolanek's Rose, Early Harmony, Early Rose Charm, 50c.
No. 2 Collection contains one packet each of Early Rose Charm, Early Blue Bird, Early Fairmaid, Early Heather Bell, Early Aviator, Early All White, Early Othello, Early Harmony, Early Zvolanek's Rose, Early Glitters, 75c.

\section{VEGETABLE SEEDS FOR FALL PLANTING}

(All prices other than packets are subject to change without notice.)

\section{BEET}

Crosby's Egyptian

Improved Blood Turnip

Detroit Dark Red

\section{CABBAGE}

Early Jersey Wakefield.

Copenhagen Market

Premium Flat Dutch

\section{CARROT}

French Forcing

Danver's Half Long.

Improved Long Orange-

\section{CAULIFLOWER}

Early Snowball

Veitch's Autumn Giant.....................................

ENDIVE

Green Curled

Broad Leaved Batavian........-......................... .10

\section{KALE}

Tall Green Curled Scotch

Jersey or Chicken....................................................

LETTUCE

Big Boston.-.

Los Angeles...

White Paris Cos
Per Per Per

$.10 \$ .20 \quad \$ .45$

.10

.20

.35

.35
.50
.25

1.00

1.50
.75

.75

.20

.20

.50

.45
.45

2.50

7.50
2.00

.20

.20

.20

.20
.20

.25

.25
ONION

Australian Brown

Yellow Flat Danvers

White Portugal

\section{PARSLEY}

Double Curled

PEAS

American Wonder

Stratagem

Laxton's Progress

Telephone

\section{RADISH}

Early Scarlet Turnip, white tipped............ Icicle

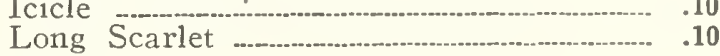

SPINACH

Bloomsdale Savoy

Prickly

TURNIP

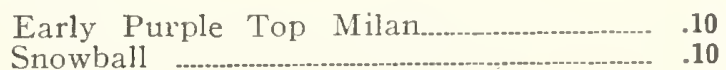

Snowball

Golden Ball
Per Per Per $\$ .10 \$ .20 \$ .60$ $\begin{array}{ll}.20 & .60 \\ .25 & .75\end{array}$ $.25 \quad .75$

.28

.45

Per

Lb.

.35
.35

.35

.35

Per Per Per

.45

.45 $\begin{array}{ll}.10 & \\ .10 & -\end{array}$ .10
.10 


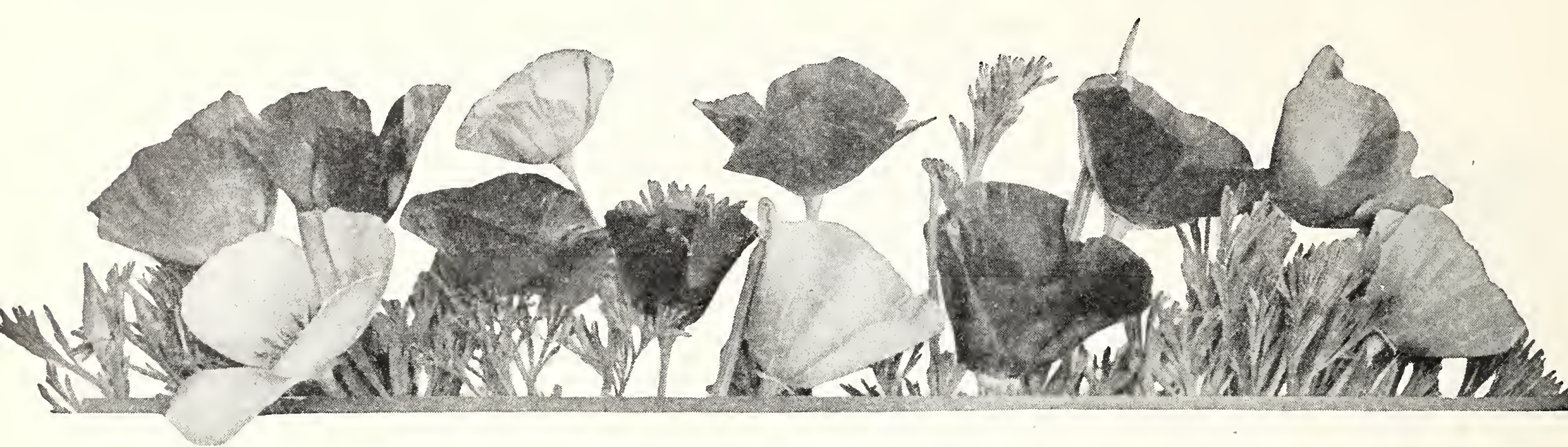

Eschscholtzias, or California Poppies

\section{Flower Seeds for Fall Planting}

For complete cultural directions and descriptions see our General Catalog

Per pkt.

Achillea: The Pearl; (perenniai)

Agrostemma Coronaria (Rose of Heaven); (perennial)...Alyssum: Lilac Queen; (annual)

“ Sweet; (annual)

“ Little Gem; (annual)...

“ Saxatile Compactum; (perennial)

Anchusa Italica: Dropmore; (perennial).

Anchusa Capensis: (annual)

Arctotis Grandis (African Lilac Daisy); (annual)...........

Aubrietia Graeca.

Bartonia Aurea: (annual)

Calendula (Cape Marigold); (annual); Orange King........

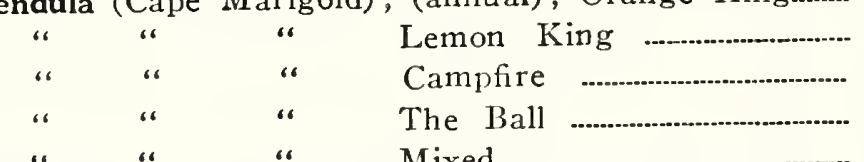

Candytuft: (annual); Carmine...

The Ball

Rose Cardinal

Lavender

Crimson or Purple..................-.....-...

Giant Hyacinth Flowered.

Mixed

Sempervirens; (perennial); white

Gibraltarica ; (perennial); lilac...

Canterbury Bells: (biennial); Single Lavender...

" Single Blue

Single Pink .

Single White

Single Mixed

Cup and Saucer Pink

Cup and Saucer White.

Cup and Saucer Blue......

“ Cup and Saucer Lavender

“ Cup and Saucer Mixed.

Carnation (perennial); Chabauds Giant White...

"

" ، “ ، “

" ، “ ، “ “

" "

Centaurea "Sweet Sultan": (annual); Mixed

\begin{tabular}{|c|c|c|}
\hline “ & “ & Rose \\
\hline “ & “ & Purple \\
\hline “ & “ & Amaranth \\
\hline “ & “ & White \\
\hline “ & “ & Lavender \\
\hline “ & “ & Yellow \\
\hline
\end{tabular}

$\$ .15$

.10

.10

.10

.10

.10

.15

.10

.10

.15

.10

.10

.10

.15

.15

.10

.10

.10

.10

.10

.10

.10

.20

.10

.10

.10

.10

.10

.10

.15

.15

.15

.15

.10

.20

.20

.20

.20

.20

.15

.10

.10

.10

.10

.10

.10

.10

Per pkt.

Centaurea "Cornflower": (annual); Double Blue................ $\$ .10$ Double Mixed ……......................... $\quad .10$

Cheiranthus Allioni: (perennial)............................................... $\quad .10$

Chelone Barbatus Torreyi: (perennial) $\ldots \ldots$

Cineraria: Hallawell's Prize Mixed_._._- .35

“ Good Mixture ........_.

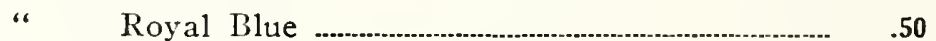

“ Terra-Cotta Red ………….......- $\quad .50$

“ Sky Blue ........ $\quad .50$

“ Rose ...

“ Stellata Mixed ....................................................... $\quad 25$

Clarkia: (annual; Double Mixed................................................. $\quad .10$

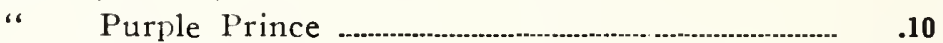

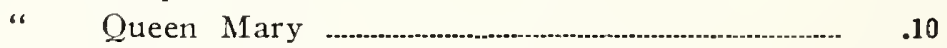

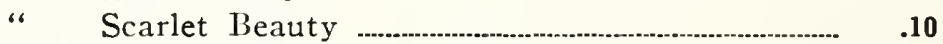

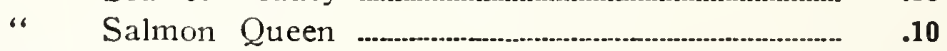

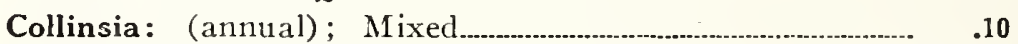

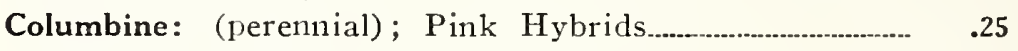

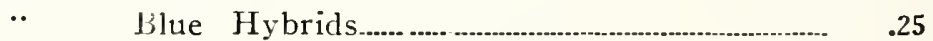

“ Orange and Scarlet Hybrids_- $\quad .25$

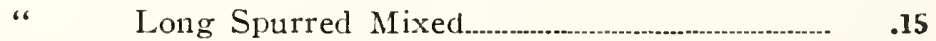

، Mrs. Scott Elliott's Strain Mixel.................

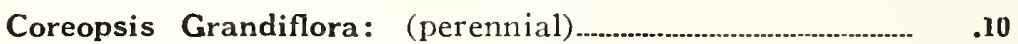

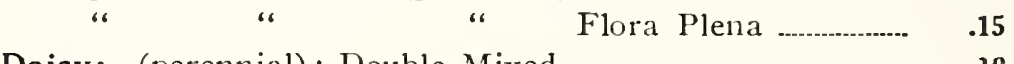

Daisy: (perennial); Double Mixed.................................................

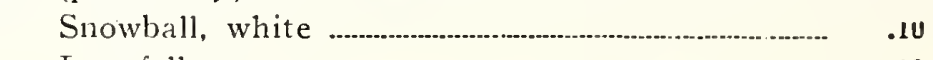

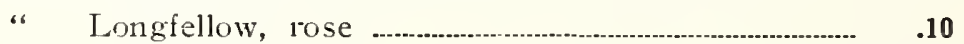

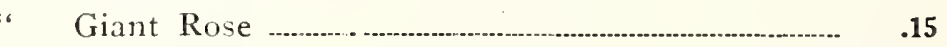

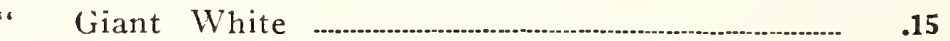

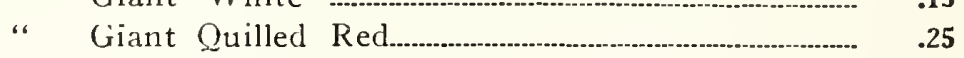

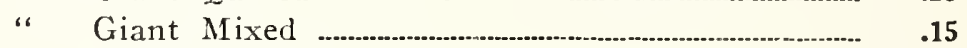

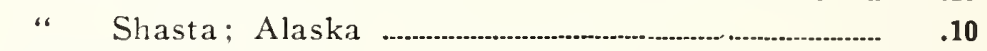

Dianthus or Clove Pinks: (perennial); Single .................... $\quad .10$

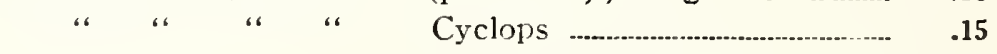

“ “ “ “ “

Eschscholtzia: California, Reselected, Orange $\quad .15$

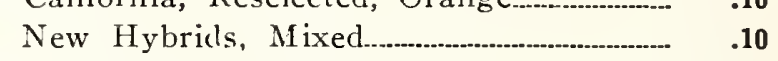

Forget-Me-Not: (perennial); Alpestris, blue___._._..... $\quad .10$

Foxglove "Digitalis": (perennial); White_._................. $\quad .10$

" " 10

$\begin{array}{ll}\text { Rose } & .10 \\ \text { Purple } & .10\end{array}$

Mixed ........................................ $\quad .10$

Giant Shirley Mixed.....................

Gaillardia: (perennial); Grandiflora Mixed._._._._....... $\quad .10$

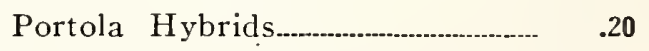

Geum: (perennial); Lady Stratheden, yellow................... 


\section{FLOWER SEEDS FOR FALL PLANTING-Continued}

Per plit.

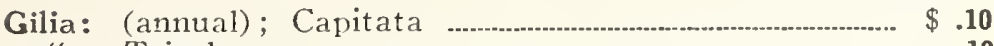

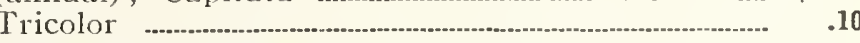

Godetia: (annual); Double Rosy Morn _..._........................ . .10

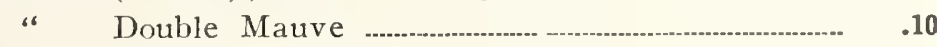

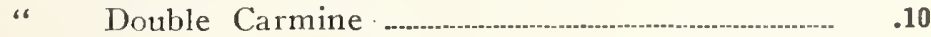

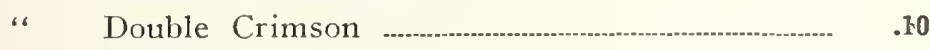

“ Double Rose

“ Double Mixed ........-...-.

Gypsophila: (annual); Elegans Grandiflora.. Elegans Carminea (perennial); Paniculata.

Heuchera Sanguinea: (perennial)

Hollyhock (perennial); Double Mixed

\begin{tabular}{|c|c|c|}
\hline & & ouble R \\
\hline & & ouble $\mathrm{W}$ \\
\hline & & ouble Y \\
\hline & & ouble R \\
\hline & & ouble $\mathrm{M}$ \\
\hline 8 & & ouble $\mathrm{P}$ \\
\hline & & nnual) \\
\hline ks! & & Delphin \\
\hline "6 & & \\
\hline 6 & “ & \\
\hline ، & 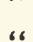 & \\
\hline ، & ، “ & \\
\hline “ & “، & “6 \\
\hline
\end{tabular}

ite ....

Oeuble Yellow

Double Maroon

Double Pink

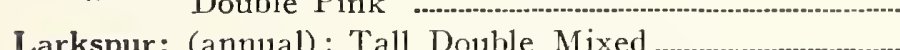

Larkspur or Delphinium:

\begin{tabular}{|c|}
\hline Belladonna Improved...... \\
\hline Light Blue Shades....... \\
\hline Deep Blue Shades..... \\
\hline Pastel Shades ........... \\
\hline Improved Hybrids \\
\hline Hollyhock or Wrexha \\
\hline
\end{tabular}

Lathyrus Latifolius (Per. Pea): White Pearl.......................

$$
\begin{aligned}
& \text { “ “ } \\
& \text { " Mixed ............ }
\end{aligned}
$$

Lupin Polyphyllus: (perennial); White.

$$
\begin{aligned}
& \text { "، } \\
& \text { "، } \\
& \text { “ } \\
& \text { " ، " “ } \\
& \text { " " " " } ، \text { Rose }
\end{aligned}
$$

Lychnis: (perennial); Haageana Mixed

$$
\text { ychnis: (perennial); Haageana Mixed... }
$$

Mignonette: (annual); Sweet-Scented

$\begin{array}{cl}\text { Machet } \\ \text { “ } & \text { Hallawell's Triumph }\end{array}$

Nemophila: (annual); "Baby Blue Eyes",

Pentstemon: (perennial); Giant Mixed.

Phacelia Campanularia: (annual).

Phlox: (annual); Fine Mixed.

Platycodon Grandiflora: (perennial)

Poppy: (annual); $\begin{aligned} & \text { Shirley Mixed... } \\ & \text { Eldorado Mixed }\end{aligned}$

$$
\text { Eldorado Mixed }
$$

(perennial); Oriental; Orientale; red

Princess Victorin; salmon Hybrids Mixed..-------o--o--.-

Iceland: Orange

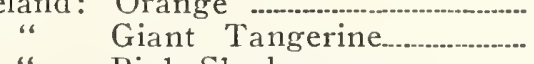

Pink Shades

New Hybrids Mixed...--..-.-.-.. Sunbeam Imp. Mixture....

Potentilla: (perennial); Single Mixed

$$
\text { Double Mixed.. }
$$

Primula Polyanthus: (perennial); Choice Mixed...................

Pyrethrum: (perennial); Golden Feather.

Hybridum Grandiforum Mixed

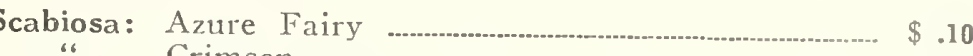

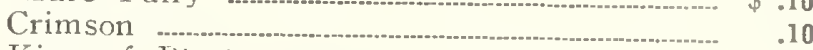

King of Blacks _.....

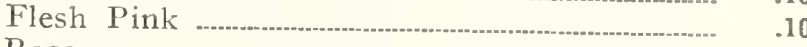

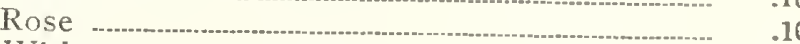

White

Collection of 6 sorts for $50 \mathrm{c}$.

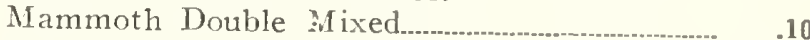

Giant Loveliness: Delicate salmon-rose-_--- $\quad .25$

Schizanthus: (annual); Grandiflorus Mixed.................... Hallawell's Select Mixture

Snapdragon: Tall, Large Sorts:

Crimson King; rich crimson _................. .10

Golden King; clear yellow

Queen Victoria; pure white.......................

Rose Queen, soft pink $\quad .10$

Fire King; orange scarlet, white tube...... $\quad \begin{array}{ll}.10 \\ \text { C... }\end{array}$

Harmony; terra-cotta pink; buff lip........... $\quad .10$

Coral Rose; coral rose

Torchlight; orange with yellow lip_.......... $\quad .10$

Collection of 6 pkts. of any of the above sorts for $50 \mathrm{c}$.

Tall Mixed

Intermediate, Large Sorts:

Amber Queen; amber, suffused chamois pink ........................ 10

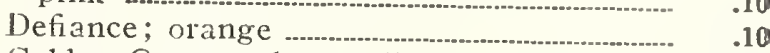

Golden Queen; clear yellow...-...-...-...-...- $\quad .10$

Purity; pure white ..- .10

Prima Donna; terra-cotta pink, white

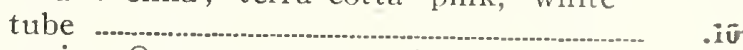

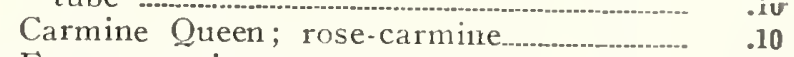

Empress; crimson .....................................

Pink Perfection; pink

Rose Dore; coral-rose

Silver Pink; pearly pink $\ldots$

Nelrose; deep rose-pink

Collection of 6 of any of the above sorts for $50 \mathrm{c}$.

Intermediate Mixed

Stock: Winter Flowering (Giant Perfection):

Lavender-pink (Abundance)

Flesh (Beauty of Nice).

Crimson (Crimson Ning) $\quad .15$

Heathan Beauty; rose sinaded terra-cotta...- $\quad .15$

Pale Blue (May Queen) $\quad .15$

White (Mont Blanc)

Yellow (Monte Carlo) pale yellow......................

Lavender (Parma Violet)_.._-_.

Purple (Summer Night)

Collection of 6 of any of the above sorts for $75 \mathrm{c}$

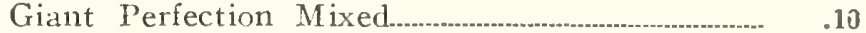

Empress Elizabeth; rosy carmine

Sweet William: (perennial); Single Mixed___- .10

$\begin{array}{ll}\text { Double Mixed ... } & .10 \\ \text { Newport Pink; salmon-rose } & .15\end{array}$

Scarlet Beauty; scarlet $\quad .15$

Verbena: (perennial); Pink 10

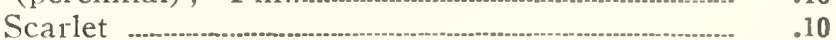

White 10

Purple with White Eye-_o

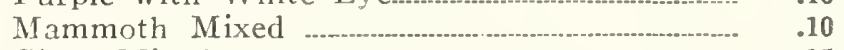

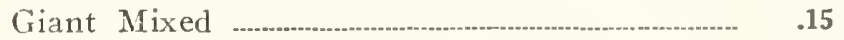

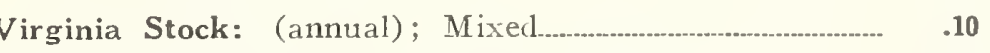

Viola "Tufted Pansy": (perennial); Mixed.......-. $\quad .10$

$\begin{array}{ll}\text { White Perfection; white.........-. } & .15 \\ \text { Lutea Grandiflora; y ellow...-...- } & .15\end{array}$

$\begin{array}{ll}\text { Lutea Grandiflora; yellow....-.-. } & \mathbf{1 1 5} \\ \text { Violet Perfection; deep blue.-.- } & .15\end{array}$

Papilio; lavender, white eye....... $\quad .15$

Apricot; apricot-tinged orange .25

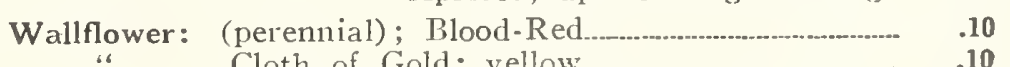

Cloth of Gold: yellow $\quad .10$

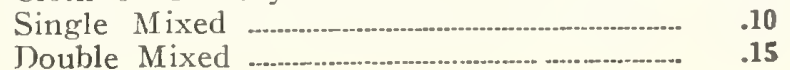




\section{Herbaceous and Perennial Plants}

\section{FOR FALL PLAN'TING}

If wanted by parcel post within the 2 nd zone, add $10 \mathrm{c}$ for one plant and $3 c$ extra for each additional plant (except where noted) to cover postage and packing. 6 plants of a variety at dozen rate.

\section{ACHILLEA (Milfoil or Yarrow)}

Plants suitable for dry, sunny places; bloom all summer.

Filipendulina: Flat heads of brilliant yellow flowers; finely cut foliage. 4 feet. 4 -inch pots, each $25 \mathrm{c}$; doz. $\$ 2.50$.

Roseum: Flowers pink in dense heads 18 inches high. 4-inch pots, each $25 \mathrm{c}$; doz. $\$ 2.50$.

\section{ACONITUM (Monkshood)}

Summer and Fall flowering hardy perennials with bold spikes of hood-shaped flowers, thriving in either sun or shade. Do not plant near vegetable garden as roots are poisonous.

Napellus-True Monkshood: Bright blue flowers. 3 to 4 feet. June, July. 4-inch pots, each 35c; doz. $\$ 3.50$.

Sparks' Variety: Tall branched spikes covered with deep blue flowers. July, August. 4-inch pots, each $35 \mathrm{c}$; doz. $\$ 3.50$.

Wilsoni: Tall growing. 5 to 6 feet, with violet-blue flowers. Very late fall. 4-inch pots, each 35c; doz. \$3.50.

\section{AGAPANTHUS \\ (Blue African Lily)}

The flowers are bright blue and are produced in clusters of 20 to 30 on stalks 3 feet tall. They bloom for a long period in the summer and fall.

They will grow in a sunny or partially shaded location. Gallon cans. Each 50c; doz. \$5.50.

\section{AGATHEA COELESTIS (Blue Marguerite)}

Sky-blue flowers with yellow disc growing 1 foot. Perennial, remaining in bloom all year round. Useful for window boxes. 4 -inch pots, each $25 c$; doz. $\$ 2.50$.

\section{ALYSSUM SAXATILE}

An excellent low growing drought-resisting plant for rockwork or the border. Its masses of broad, flat heads of bright yellow flowers are produced in May. Its leaves are evergreen and a good ground cover. 4-inch pots, each $25 \mathrm{c}$; doz. $\$ 2.50$.

\section{ANCHUSA-Dropmore Variety}

One of the best hardy perennials, growing about 5 feet high. The stems are covered all summer with numerous wide star flowers of intense blue. Should be in every hardy border. Strong plants, each $15 \mathrm{c}$; doz. $\$ 1.50$.

\section{ANEMONE JAPONICA}

The Japanese Wind-Flowers are among the most beautiful of our fall flowering plants. They bloom in wonderful profusion from August until late in the fall and attain a height of 4 to 5 feet. They require a partially shaded location; also fine as a cut flower.

Queen Charlotte: Silvery-pink.

Alba: Pure white.

Rubra: Rosy-red.

3 -inch pots, each $25 \mathrm{c}$; doz. $\$ 2.50$.

\section{AQUILEGIA (Columbine)}

Columbines are among the most beautiful hardy perennials producing gracefully spurred flowers on stems 2 to 3 feet tall throughout May and June.

Mrs. Scott Elliott's Hybrids: 1 year old. Each 15c: doz. $\$ 1.50$. Blue Hybrids: 2 years old. Each $25 \mathrm{c}$; doz. $\$ 2.50$.

Pink Hybrids: 2 years old. Each 25c: doz. $\$ 2.50$.

\section{ARABIS ALPINA (Rock Cress)}

Similar to the Alyssum or Golden Tuft, but with double pure white flowers from early spring until summer. 4-inch pots, each $25 \mathrm{c}$; doz. $\$ 2.50$

\section{ARENARIA CAESPITOSA (Irish Moss)}

Makes a vivid green carpet an inch or so high and spreads rapidly. Fine for rock gardens and flag walks. Sections 25c each; postpaid 35c; Flats $\$ 2.50$ each, express collect.

\section{AUBRIETIA GRAECA}

One of the daintiest of all dwarf creeping plants for carpeting beds or rockwork, forming brilliant sheets of blue for many weeks. 4-inch pots, each $25 \mathrm{c}$; doz. $\$ 2.50$.

\section{HARDY ASTERS (Michaelmas Daisies)}

Climax: Extra large violet-blue flowers. 2 inches across,

4 feet tall; verv fine.
White Climax: White form of the preceding variety.

Roseum Superba: Deep, bright-rose and a very free bloomer. 3 to 4 feet tall.

St. Egwin: A pleasing soft rosy-pink of medium size; very free flowering of fine compact habit; 2 to 3 feet tall.

Sub-Coeruleus: Forms a dense tuft of leaves, from which issue many leafless stems 12 inches high bearing light blue flowers 3 inches in diameter in great profusion, during June and July. Useful for rockery or edge of hardy border.

4 -inch pots, each $25 \mathrm{c}$; doz. $\$ 2.50$.

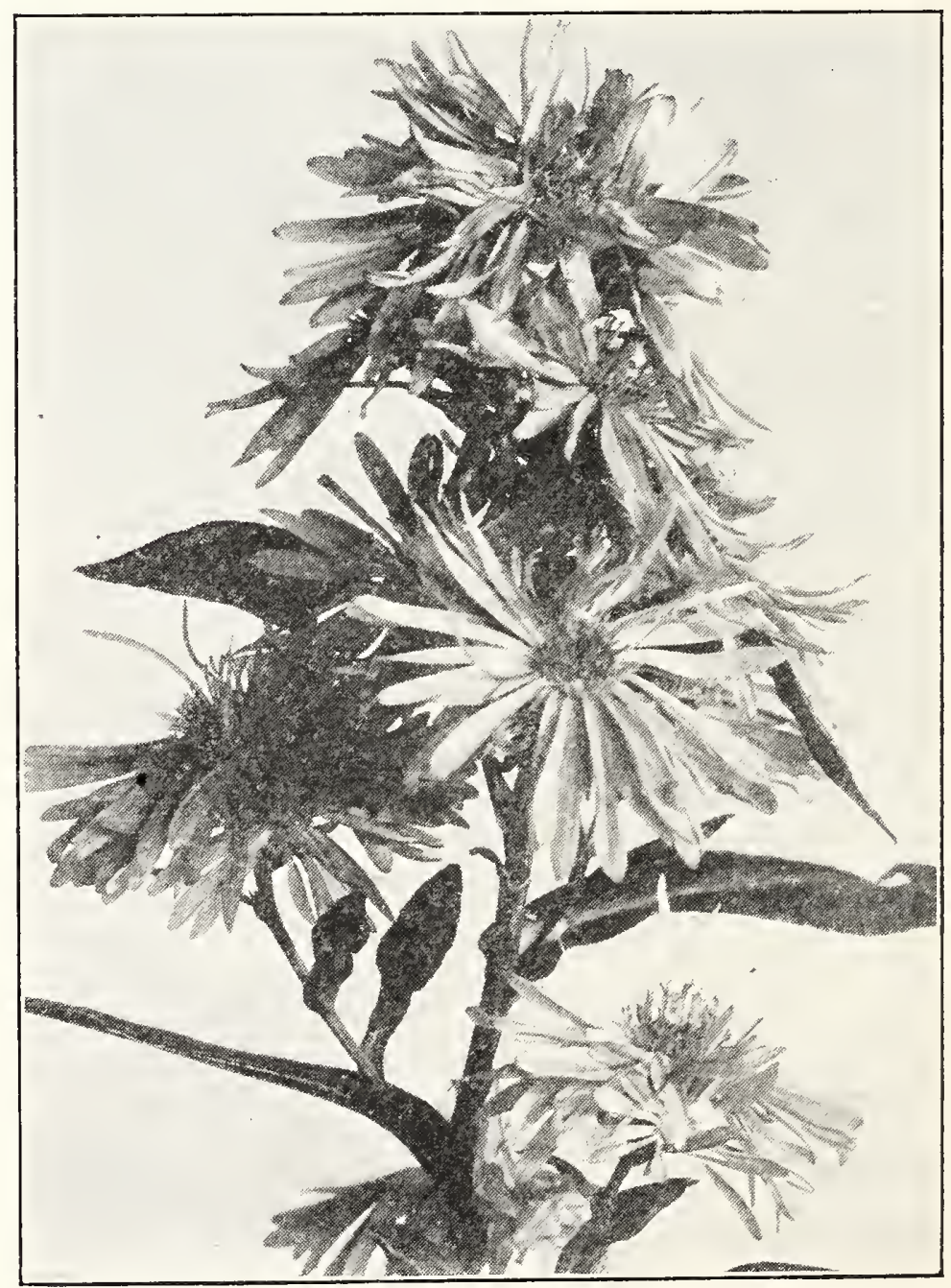

Hardy Aster 


\section{Herbaceous and Perennial Plants ${ }_{1}$ Continued}

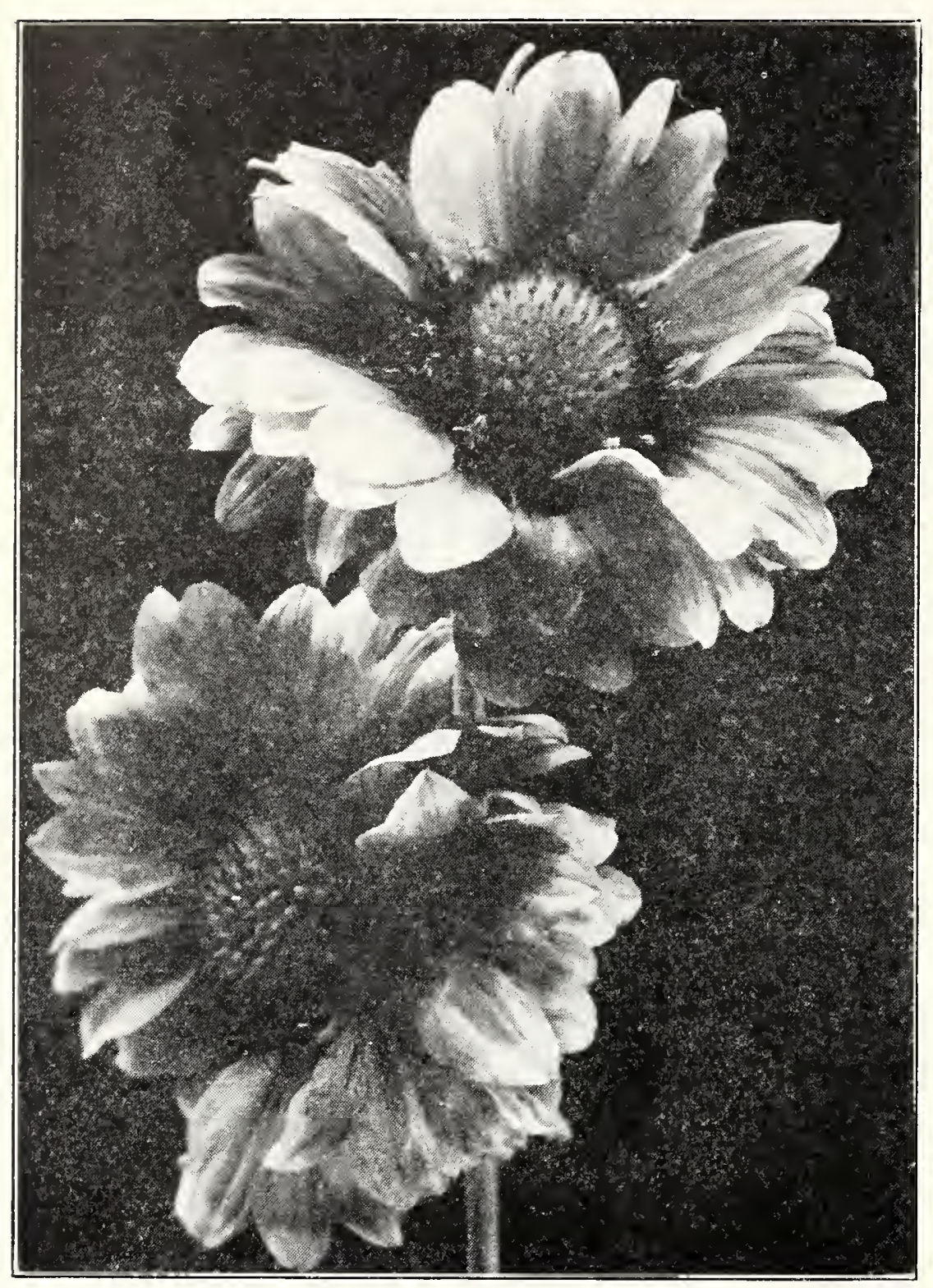

Gaillardia, Portola

\section{GAILLARDIA}

Very showy hardy perennials, growing $1 \frac{1 / 2}{2}$ to 2 feet high and blooming all summer. Flowers are scarlet and yellow, blended and shaded, 3 inches in diameter, produced on long stems.

Grandiflora Hybrids: Extra large clumps, Each 15c; doz. \$1.25. Portola: The flowers are of enormous size beautifully zoned with golden yellow at the margins of the petals, while the interior is a rich crimson bronze. Splendid for cutting. Strong plants. Each 25c; doz. $\$ 2.50$.

\section{GEUM}

A showy hardy perennial with large brilliant flowers borne on long stems, blooming nearly all summer, fine for cutting. 2 feet high.

Mrs. Bradshaw: Large double orange-scarlet flowers. Strong plants. Each $15 \mathrm{c}$; doz. $\$ 1.25$.

Lady Stratheden: Fine rich golden-yellow flowers which match in other respects the popular scarlet variety, Mrs. Bradshaw. Strong plants. Each 15c; doz. \$1.25.

\section{HEUCHERA (Coral Bells)}

Sanguinea: A low growing plant with heart-shaped leaves which form a low clump 6 to 8 inches high and bearing during early Summer loose graceful sprays of coral-red flowers in great profusion; suitable for the border or rockery and thriving in the shade or in cool places in the sun. 2-year-old clumps. Each 15c; doz. $\$ 1.50$.
If wanted by parcel post within the 2 nd zone, add $10 \mathrm{c}$ for one plant and $3 \mathrm{c}$ extra for each additional plant (except where noted) to cover postage and packing. 6 plants of a variety at dozen rate.

\section{HOLLYHOCK}

A hardy perennial of upright growth, 5 to $\&$ feet high. Double Rose-Pink, Double Red. Double Yellow, Double Pure Pink, Double Maroon, Double White. Strong field grown plants. Each 15c; doz. $\$ 1.50$.

\section{IBERIS (Perennial Candytuft)}

A most desirable dwarf plant for the front of the border and one of the best rock plants. The foliage is evergreen and is completely hidden with dense heads of white tinted lilac flowers in early spring; withstands drought. 4-inch pots. Each $25 \mathrm{c}$; doz. $\$ 2.50$.

\section{LAVANDULA (Sweet Lavender)}

Fragrant blue flowers, from July to September. 4-inch pots. Each $25 \mathrm{c}$; doz. $\$ 2.50$.

\section{LOBELIA}

Cardinalis-A most brilliant colored hardy perennial, succeeding best in a moist, deep loam. The rich, fiery cardinal flowers are produced on spikes often 24 to 30 inches high. In bloom from early in August to late in September. 3-inch pots, each $25 \mathrm{c}$; doz. $\$ 2.50$.

Tupa-A very strong growing, shrubby perennial, 4 to 7 feet tall. The large blood-red flowers are 2 inches long with a hooded lip curving downwards and are borne on long terminal racemes. A rare and beautiful Summer blooming variety. 4-inch pots, each 35c.

\section{LYTHRUM ROSEUM SUPERBUM}

A strong growing plant, 3 to 4 feet high, thriving in almost any position, producing large spikes of rosy purple colored flowers from July to September. Clumps. Each 25c; doz. $\$ 2.50$.

\section{NEPETA MUSSINII}

A hardy dwarf compact perennial, producing clouds of light blue flowers from May to September. Makes a fine permanent edging and an excellent rock plant. 10 inches high when in bloom. 3-inch pots. Each 25c; doz. $\$ 2.50$.

\section{OENOTHERA (Evening Primrose)}

Lamarckiana: A tall, strong and much branched sort, with large yellow flowers 3 to 4 inches in diameter. Flowers produced in great freedom from June until October. Requires a sunny situation. 4-inch pots. Each $25 \mathrm{c}$; doz. $\$ 2.50$.

\section{ORIENTAL POPPIES}

A charming summer-flowering hardy plant, producing numerous leafy stems about $2 \frac{1}{2}$ feet high, with large, showy flowers, having a conspicuous black blotch on each petal; exceedingly showy.

Red, Salmon-Pink, Orange or Mixed Colors: 3-inch pots. Each 15c; doz. $\$ 1.50$.

\section{ICELAND POPPIES}

The plant is of neat habit, forming a tuft of bright green fernlike foliage, from which spring throughout the entire season a profusion of beautiful cup-shaped flowers on slender leafless stems 1 foot high.

Yellow, Orange-Scarlet and Pink Shades. 3-inch pots. Each $15 \mathrm{c}$; doz. $\$ 1.50$.

\section{PENTSTEMON}

A hardy perennial growing 2 feet high, sending up spikes of bright colored and spotted flowers. Somewhat like the Foxglove but in a great variety of colors.

Mixed Colors: Field grown plants. Each 15c; doz. \$1.50. 


\section{Herbaceous and Perennial Plants $>$ Continued}

\section{PERENNIAL HARDY PHLOX}

A beautiful and easily grown perennial about 3 feet high, producing magnificent spikes of showy flowers. They remain in bloom all summer; set the plants 18 inches apart.

Baron von Dedem: Large flowers and trusses of a glistening scarlet-blood-red.

Elizabeth Campbell: Light salmon-pink with lighter shadings and dark red eye.

Eugene Danzanvilliers: Soft lavender with large white center. Frau Antoine Buchner: Large trusses of pure white.

Rijnstroom: Irnmensé flowers and trusses of a beautiful clear pink. Extra fine.

Thor: Deep salmon-pink, crimson eye.

Any of the above in separate colors or assorted in strong plants. Each 25c; doz. $\$ 2.50$.

\section{PYRETHRUM HYBRIDUM GRANDIFLORUM}

Single Mixed: A hardy perennial with giant single daisy-like flowers appearing in June and continuing throughoist the summer. The foliage is low and fern-like and the flowers are borne on long slender stems.

Extra strong plants. Each 25c; doz. $\$ 2.50$.

\section{REHMANNIA ANGULATA}

A half-hardy herbaceous perennial with beautiful large rosy. purple, gloxinia - like flowers. Suitable for pot culture or outdoors in a sheltered situation. 3 feet tall. 3 -inch pots. Each $25 \mathrm{c}$; doz. $\$ 2.50$.

\section{RUDBECKIA (Cone Flower)}

Laciniata Fl. Pl. (Golden Glow): Handsome perennial, 6 to 8 feet high, covered with very double golden yellow flowers in summer time. Clumps. Each $15 \mathrm{c}$; doz. $\$ 1.50$.

Purpurea Grandiflora (Purple Cone Flowers): Large, handsome crimson-purple flowers with dark central disc. 3 feet tall. 3-inch pots. Each 25c; doz. $\$ 2.50$.

\section{SALVIA AZUREA}

A hardy perennial variety growing 3 to 4 feet high and producing during late summer panicles of pretty sky-blue flowers in great profusion. It requires a sunny situation and will stand considerable drought. 3-inch pots. Each 25c; doz. $\$ 2.50$.

\section{SAXIFRAGA}

Crassifolia: A large-growing hardy plant with large leaves, especially adapted for shady places. Bears good-sized pink flowers in a large panicle rising to a foot above the ground. Commences to bloom in the fall and continues through the winter. 4-inch pots. Each $30 \mathrm{c} ;$ doz. $\$ 3.00$.

Umbrosa: Is the London Pride and a dainty plant with erect flowering stems about a foot high and many small white flowers. The foliage is pretty and tufted, and it spreads to form a fine colony. 3-inch pots. Each 25c; doz. $\$ 2.50$.

\section{SCABIOSA CAUCASICA (Blue Bonnet)}

One of the handsomest of hardy perennials. 3 feet. Large pale blue flowers on long stems; fine for cutting. 2-year-old. Each 25c; doz. $\$ 2.50$.

\section{SHASTA DAISY}

Alaska: A most satisfactory perennial, blooming very profusely for a long period. The flowers are single white, yellow center, and borne on long, stiff stems. Extra large clumps. Each 15c; doz. \$1.25.

Fringed: A new semi-double sort with many narrow petals; fine for cutting. Each $25 \mathrm{c}$; doz. $\$ 2.50$.

\section{SOLIDAGO (Golden Wings)}

The finest of all; 5 feet high with immense pannicles of bright golden-yellow flowers from July to September. Strong roots. Each 20c; doz. $\$ 2.00$.

\section{STOKESIA (Cornflower Aster)}

Cyanea: Deep lavender-blue flowers, 4 inches in diameter Very free bloomer of the easiest culture. 3-inch pots. Each 25 c; doz. $\$ 2.50$.

\section{SWEET WILLIAM (Dianthus Barbatus)}

A very desirable low-growing, free-flowering hardy perennial, producing a splendid effect in beds and borders with their rich and varied flowers.

Newport Pink: Brilliant single salmon-rose.

Scarlet Beauty: Bright scarlet.

Single Mixed: All colors.

Extra large clumps. Each 15c; doz. \$1.25.

\section{THALICTRUM( Meadow Rue)}

Dipteriocarpum: The finest of all. This hardy perennial is of vigorous growth, 4 to 5 feet high. The dainty rosy purple flowers are brightened by a bunch of conspicuous yellow stamens and produced in graceful sprays from July to September. Clumps. Each 25c; doz. $\$ 2.50$.

\section{TRACHELIUM COERULEUM}

A free-flowering perennial producing large cloud-like heads of pale mauve fowers, resembling the Gypsophila; $11 / 2$ feet high. 3-inch pots. Each $25 \mathrm{c}$; doz. $\$ 2.50$.

\section{TRITOMA (Red Hot Poker)}

Hardy plants with large and broad grassy leaves at the base; the dense spikes of brilliant flowers are borne on long, stiff stems during the summer months; withstands drought. Pfitzeri: Orange-scarlet spikes. 3 to 4 feet high; very effec-

tive. Clumps. Each 35 ; doz. $\$ 3.50$.

\section{VALERIAN (Centranthus Ruber)}

Showy, hardy border plants, producing large corymbs of red or white flowers. They are drought-resisting and remain in bloom for many months. Excellent for the shady border. 2 to 3 feet tall. Crimson and White. Field grown plants. Each 15c; doz. \$1.50.

\section{VERBASCUM (Mullein)}

Olympicum: A stately hardy perennial plant attaining a height of 6 feet. The large leaves are covered with a silvery down, above which rises a pyramid of bright yellow flowers. 4 -inch pots. Each $35 \mathrm{c}$; doz. $\$ 3.50$.

\section{VIOLA (Tufted Pansy)}

Jersey Gem: A superb variety with pure violet-blue flowers which have a little perfume. The plant is of compact, sturdy habit of growth and the flowers are borne on good stems about 6 inches long, making it ideal for cutting as well as a most desirable plant for the border or rockery. 3-inch pots. Each 25c; doz. \$2.50.

Radio: A new variety of a decided lavender-blue, used extensively for cut flowers by the leading local florists. Of extremely free flowering habit. 3 -inch pots. Each 25c; doz. $\$ 2.50$.

\section{VIOLETS}

California: Large, single blue. Strong roots. Doz. 50c; postpaid $60 \mathrm{c} ; 100 \$ 3.50$; prepaid. 


\section{Superb Collection of}

\section{Pkts. Spencer Sweet Peas, $\$ 1.00$}

Austin Froderick Improved: Giant lavender. Olympia: Deep rich purple.

Avalanche: Pure white.

Pinkie: Giant clear deep pink.

Reflection: Rich, clear blue.

Charming: Glowing rose, salmon sheen.

Crimson King: Rich deep crimson.

Del Monte: Salmon-cerise-pink.

Huntsman: Brilliant scarlet, sunproof.

Mary Pickford: Cream-pink suffused salmon. Youth: Pure white margined with pink.

Royal Pink: Shrimp-pink and orange.

Supreme: Large pale pink.

Warrior: Dark maroon.

Wembley: Lavender suffused blue.

\section{Special Collection of}

\section{Pkts. Spencer Sweet Peas, 50c}

Austin Frederick Improved: Lavender.

Avalanche: Pure white.

Charming: Glowing rose, salmon sheen.
Crimson King: Rich deep crimson. Pinkie: Giant clear deep pink.

Reflection: Rich, clear blue.

Supreme: Large pale pink.

\section{Collection of 6 Pkts. \\ Winter Flowering Spencer}

\section{Sweet Peas, 50c}

Early All White: Pure white.

Early Aviator: Crimson-scarlet.

Early Glitters: Bright fiery orange.
Early Rose Charm: Bright rose. Early Harmony: Clear lavender.

Early Zrolanek's Rose: Rose-pink.

\section{HALLAWELL'S Prize Strain Pansies}

Packet of 500 Seeds ......... 50 Cents 